\title{
Contributions
}

Valentina Dimitrova-Grajzl, Peter Grajzl*, A. Joseph Guse and J. Taylor Smith

\section{Racial Group Affinity and Religious Giving: Evidence from Congregation-Level Panel Data}

DOI 10.1515/bejeap-2015-0131

Published online January 20, 2016

Abstract: Since giving to religious organizations constitutes a substantial portion of total charitable giving, an understanding of the determinants of religious giving is a vital policy concern. Drawing on a novel congregation-level panel dataset, we examine whether religious giving is driven by preferences for racial group affinity, that is, loyalty to one's own racial group. To address endogeneity concerns, we combine a fixed effects estimation framework with an instrumental variable approach. We find robust evidence consistent with the racial group affinity motive: a decrease in the percent of whites in the local community is ceteris paribus associated with a decrease in the total giving receipts collected by predominantly white congregations. The magnitude of this effect does not vary with the extent of racial residential segregation in the community. The effect, however, is driven by the congregations in urban (as opposed to rural) communities. We offer a possible explanation for this result.

Keywords: religious giving, racial group affinity, diversity, congregations JEL Classifications: D64, L31, Z12, J15

\section{Introduction}

In the United States, giving to religious organizations constitutes more than $50 \%$ of total charitable giving (Schervish, O'Herlihy, and Havens 2006, 34). Religious

Correction Note: Correction added after online publication 20 January 2016: The author information on A. Joseph Guse stated incorrectly that he was affiliated with CESifo, Munich, Germany.

*Corresponding author: Peter Grajzl, Department of Economics, Washington and Lee University, 204 West Washington St., Lexington, VA 24450, USA and CESifo, Munich, Germany, E-mail: grajzlp@wlu.edu

Valentina Dimitrova-Grajzl, Virginia Military Institute, Lexington, VA, USA

A. Joseph Guse, Department of Economics, Washington and Lee University, Lexington, VA, USA J. Taylor Smith, Georgia Gwinnett College, Lawrenceville, GA, USA 
organizations, in turn, use a portion of these funds to provide a wide range of social services. Referring to Solomon (2003), Hungerman $(2008,380)$ reports that "[o]f the more than 350,000 congregations in the country, more than $85 \%$ support some type of social service activity." Thus, an understanding of the determinants of religious giving is a vital concern for policy makers.

In this paper, we test the hypothesis that religious giving is shaped by preferences for racial group affinity, that is, loyalty to one's own racial group. Drawing on a unique and thus far unexplored congregation-level dataset, we examine whether, and to what extent, the total receipts from giving collected by the predominantly white congregations of a major evangelical denomination in one US state are affected by the share of whites in the congregation's community. ${ }^{1}$

Given that globalization and lower barriers to mobility have led to steadily increasing ethnic and racial diversity across communities, ascertaining how religious giving responds to racial composition of the local community is relevant for prediction of future trends in charitable giving. At the same time, it is important to investigate whether in-group bias, a behavioral phenomenon identified in a variety of experimental settings studied by the literature on social psychology (see, e.g., Festinger 1954; Tajfel 1970; Tajfel et al. 1971; Brewer 1979; Mullen, Brown, and Smith 1992; Brown et al. 2000) and behavioral economics (see, e. g., Ruffle and Sosis 2006; Ahmed 2007; Ben-Ner et al. 2009; Güth, Ploner, and Regner 2009; Pan and Houser 2011; Ockenfels and Werner 2014; Chakravarty and Fonseca 2014), can also be detected in observational data in the context of religious giving.

The role of the local community's racial structure for religious giving or church charitable activity has thus far been explored in only a handful of papers. ${ }^{2}$ Drawing on data from Presbyterian congregations, Coate and Vanderhoff (2009) and Vanderhoff (2012) document that increased racial diversity in the local community is associated with more religious giving, a finding not in line with the racial group affinity hypothesis. In contrast, using three different congregation-level datasets, Hungerman (2008) shows that all-white congregations spend less on local charitable activities as the share of black residents in the community increases, a result lending support to the racial group affinity hypothesis. Thus, further empirical investigation of the phenomenon is warranted.

1 While the identity of the denomination and the state in question are held in confidence, this information was revealed to the editors and the reviewers of the journal for review purposes. To preserve confidentiality, Sections 2 and 4 of this (final) version of the paper purposefully omit citations to the underlying sources.

2 For a general overview of the interdisciplinary literature on religious giving, see Lincoln, Morrissey, and Mundey (2008). 
Aside from utilizing a newly assembled dataset, the key novelty of our approach vis-à-vis the existing studies on the role of the local community's racial structure for religious giving and church charitable activity (Hungerman 2008; Coate and Vanderhoff 2009; Vanderhoff 2012) stems from thoroughly exploiting the panel structure of our congregation-level data. As we clarify in the context of a simple theoretical framework that we develop to guide our empirical analysis, there exist compelling arguments in favor of controlling for congregation-level unobserved heterogeneity when estimating the effect of racial composition in the community on congregation-level religious giving. Specifically, the concern is that the effect of racial composition of the community on congregation-level religious giving is blurred by unobserved congregation-specific characteristics that correlate with the community's racial composition. Yet, the likely confounding role of congregation-level unobserved heterogeneity has, for various reasons, thus far not been fully addressed in the scant empirical literature on the topic (Hungerman 2008; Coate and Vanderhoff 2009; Vanderhoff 2012). ${ }^{3}$

We tackle the problem of unobserved congregation-level heterogeneity by utilizing congregation-level fixed effects analysis. Ample within-congregation variation in total giving receipts over time enables us to directly control for the confounding role of congregation-specific, time-invariant unobserved factors. The additional inclusion of congregation-specific time trends allows us to control for unobservable common trends in religious giving and racial composition of the local community. One such plausible scenario is "white flight" (Hungerman 2008) when an increase in racial diversity in the community leads to a reduction in religious giving by white congregations, not for reasons of racial group affinity, but rather because the most affluent white congregation members relocate out of the original community.

Our empirical analysis shows that controlling for congregation-level unobserved heterogeneity is indeed critical. Naïve pooled ordinary least squares (OLS) estimates suggest that religious giving is not motivated by racial group affinity; in fact, based on OLS estimates, religious giving to predominantly white congregations is ceteris paribus statistically significantly negatively associated with the share of whites in the local community. Once addressing the likely confounding impact of congregation-level unobserved heterogeneity through the

3 One of the three datasets used by Hungerman (2008) is a panel. However, by the virtue of very slow changes in congregations' racial makeup over time, Hungerman is unable to estimate his coefficients of interest sufficiently precisely if he controls for congregation-level fixed effects (2008, fn. 9). In contrast, both Coate and Vanderhoff (2009) and Vanderhoff (2012) use congregation-level panel data, but choose not to control for congregation-level fixed effects; instead, both studies control for synod fixed effects. 
inclusion of congregation fixed effects and congregation-specific time trend, however, we find a statistically significant positive association between total congregation-level receipts and the share of whites in the community, evidence consistent with racial group affinity motives.

The implied effect of racial group affinity is nontrivial in magnitude. Based on our preferred estimates using the full sample of congregation-year observations, if the percent of whites in the community decreases by 1 percentage point, the total receipts collected by a congregation decrease on average by between 0.9 and $2.5 \%$, all else equal. The positive effect of the percent of whites in the community on congregation-level religious giving is robust to inclusion of a variety of congregationand community-level controls, as well as to combining congregation-level fixed effects estimation with an instrumental variable (IV) approach aimed at even better isolating the effect of exogenous variation in the share of whites in the community.

We provide a battery of robustness checks that demonstrate the robustness of our findings. Among others, a set of tests allows us to rule out with a high level of confidence that our results cannot be attributed to white flight or an alternative, 'fortress-building', motive for religious giving. We further find that the magnitude of the positive effect of the percent of whites in the community on religious giving is, interestingly, independent of the degree of residential racial segregation of the communities in which the congregations are located. Instead, we show that the empirically salient characteristic of the community that influences the strength of the association between the percent of whites and religious giving is the community's urban versus rural status. Specifically, we find that the positive effect of the percent of whites in the community on religious giving is driven by congregations located in urban, not rural, communities. These findings resonate with the theory that, relative to the smaller and relatively more close-knit rural communities, urban communities by the virtue of their larger size and greater heterogeneity of social networks allow the residents to choose to live racially more segregated lives, which in turn plausibly perpetuates any in-group biases (see, e. g., Pettigrew and Tropp 2006).

In addition to contributing to the literature that examines the sensitivity of religious giving, religious participation and charitable church activity to the local community's characteristics (Hungerman 2008; Coate and Vanderhoff 2009; Vanderhoff 2012; Gruber 2005) and the voluminous literature on in-group bias noted above, our paper also relates to the broader literature on the relationship between diversity and socioeconomic outcomes. There are significant benefits to diversity. Diversity, for example, promotes innovation and creativity due to the mixing of different "abilities, experiences, and cultures" that different groups possess (Alesina and Ferrara 2005, 762). However, ethnic and religious diversity can also be costly due to the inability of diverse groups to agree on which public goods should be financed and what public policies should be adopted (Alesina and Ferrara 2005, 
769). Some research shows that racially or ethnically diverse communities spend less on publicly funded goods and services such as schools, roads and social programs (see, e. g., Alesina, Baqir, and Easterly 1999; Alesina, Baqir, and Easterly 2000; Alesina, Glaeser, and Sacerdote 2001; Poterba 1997; Goldin and Katz 1999; Vigdor 2004) and have worse quality of government (Lopez de Silanes et al. 1999; Alesina et al. 2003; Easterly, Ritzen, and Woolcock 2006). Other research does not find a significant, or unambiguous, effect of heterogeneity on public good provision or the functioning of the public sector (see, e. g., Cutler, Elmendorf, and Zeckhauser 1993; Gerdes 2011; Hopkins 2011). Existing work has also shown that racial or ethnic heterogeneity is associated with lower levels of trust (see, e. g., Alesina and La Ferrara 2002), less civil society involvement and fundraising (see, e. g., Alesina and La Ferrara 2000; Miguel and Gugerty 2005; Okten and Osili 2004) and fewer contributions to charities in general (Andreoni et al. 2011). ${ }^{4}$ Empirical evidence further indicates that individuals exhibit loyalty to their own racial group in the context of attitudes toward welfare spending (Luttmer 2001; Senik, Stichnoth, and Van Der Straeten 2009; Eger 2010; Dahlberg, Edmark, and Lundqvist 2012). Our analysis sheds further light on these debates by demonstrating that in predominantly white congregations of a major Christian denomination in one US state, the collected total giving receipts decrease as the share of whites in the local community decreases.

The rest of the paper proceeds as follows. In the following section, we provide a brief background on the congregations under consideration. Section 3 develops a simple conceptual framework to guide our empirical analysis. Section 4 introduces our data and variables. Section 5 develops our empirical strategy and presents the baseline results. Section 6 provides a series of robustness checks and presents additional results. Section 7 concludes.

\section{Background on the Congregations under Consideration}

The congregation-level data we utilize is on congregations that constitute a state-level congregational convention (SCC) in one US state. The SCC we study is in turn a member of a larger, regional congregational convention (RCC). According to the 2010 Religious Congregations and Membership Study (RCMS), the state under consideration is ranked in the top five of all US states in terms of religious attendance, with more than $60 \%$ of the state's population being an

4 For further references and an overview of the literature on ethnic and racial diversity and economic outcomes, see Alesina and La Ferrara (2005) and Stichnoth (2013). 
adherent to some religion. Within this state, the SCC of our interest constitutes the largest evangelical denomination and ranks second based on total adherents. The SCC in question currently has more than 1,600 local churches as members and the RCC has more than 40,000 churches nationwide.

Both the SCC and the RCC can be best described as having a bottom-up structure. That is, congregations within the convention are autonomous. As a result, individual congregations make all budgetary decisions independently and receive contributions directly from their members. At the same time, however, congregations elect to participate in the state and national convention as a way of pooling resources and in order to benefit from economies of scale in some areas of their activity (such as disaster relief or larger missions).

Given the autonomy of individual congregations within the SCC, there is no single pattern of their operations and activities that would fit them all. However, the involvement in community services with a substantial public good component is an integral part of the SCC's mission. As a result, all congregations offer some services to the surrounding community. For example, many congregations operate a benevolence ministry where the congregation provides emergency funds for food, utilities and rent to those in need. Other frequently provided services include provision of food pantries and counseling, hosting of community events and assisting with various local service projects. The extent of a congregation's involvement among others depends on the size of the congregation.

The congregations' commitment to continue serving not only its members but also the community at large is explicitly articulated in the SCC's goal that "[e]very congregation will minister to the needs of its community" as well as in the SCC's priority initiative to reach out to "every people group", and in particular "the nonAnglo [i. e. non-white] population." 5 This continued emphasis on and commitment to inclusiveness by the SCC is partly a consequence of the growing disparity between the ethnic and racial composition of the SCC congregations and the demographic trends in the SCC's residing state. Consistent with these trends, baptisms and attendance in the SCC congregations have been on a decline since 1980 (see also Section 4). In addition, the RCC has been actively trying to redress past history of racism with its 1995 resolution on racial reconciliation and the appointment of the first African-American president of the RCC in 2012.

In terms of giving to congregations, a 2013 resolution of the RCC states that the convention's congregational membership gives only about $2.5 \%$ of their annual income to the local church. This is well below the usually quoted $10 \%$ "tithe" expected of congregants. However, just as congregations differ in the

5 This information is drawn from the 2013 annual report of the SCC under consideration. 
extent of community services offered, there also exists heterogeneity among the congregations in giving by its members.

\section{Racial-Group Affinity and Religious Giving: A Simple Model}

To guide our empirical analysis, we develop a stylized model of religious giving. We do not strive to develop a general theory of religious giving. Instead, our goal is to propose a plausible micro-founded framework in which, much like in the reduced-form frameworks of within-group affinity developed by Vigdor (2002) and Andreoni et al. (2011), donor preferences for giving exhibit racial group affinity. The model allows us, first, to identify the role of some salient individual-level factors shaping religious giving. Second, the aggregation of individual donors' demands for giving at the level of a congregation - the level of aggregation at which we observe giving in our data - illustrates various sources of observed and unobserved congregation-level heterogeneity that are important to account for in empirical analysis.

Let the utility of donor $i$ who is a member of congregation $k$ located in community $c$ take on the following Cobb-Douglas form:

$$
u_{i k c}\left(\chi_{i k c}, g_{i k c}\right)=\chi_{i k c} \ln \chi_{i k c}+\left(1-\chi_{i k c}\right) \ln \left(\omega_{c}+\theta_{k c} g_{i k c}\right) \text {, }
$$

where $x_{i c k}$ is donor $i$ 's private consumption and $g_{i k c}$ is donor $i$ 's charitable gift. ${ }^{6}$ $\omega_{c}$ is the wealth endowment of $i$ 's own racial group (as the donor's target recipient group) in community $c . \theta_{k c} \in[0,1]$ is the share of donor $i$ 's gift that congregation $k$ distributes to $i$ 's racial group in community $c$. Assuming that congregations distribute gifts evenly across all racial groups in the community of their respective residence, $\theta_{k c}=\theta_{c}$ for all $k$ in a given community $c$. $\theta_{c}$ then represents the population share of donor $i$ 's racial group in the community. Finally, the parameter $\chi_{i k c} \in(0,1)$ captures the strength of donor $i$ 's preference for private consumption relative to giving.

Much like in the framework of Vigdor (2002) and Andreoni et al. (2011), utility function [1] implies that there is no public good aspect to the donor's gift. Hence, there are no free-riding effects (within the congregation or beyond) in

6 Neither the Cobb-Douglas functional form nor the assumption of linear homogeneity of eq. [1] is essential for our arguments. We rely on these assumptions to simplify the exposition and derive tractable closed-form solutions. 
this model. ${ }^{7}$ Moreover, since donor's utility does not depend on the consumption of everybody else per se, donors are not purely altruistic. Instead, the donor experiences a "warm glow" (Andreoni 1989, 1990, 2006) from giving conditional on the congregation allocating at least a portion of the donor's gift to the individuals in the donor's community who belong to the donor's own racial group. ${ }^{8}$ In particular, $\partial^{2} u_{i k c} /\left(\partial \theta_{c} \partial g_{i k c}\right)>0$ : the larger the share of the gift that the congregation allocates to the donor's own racial group, the higher the donor's marginal utility from giving. Giving is therefore motivated by racial group affinity.

The donor chooses $x_{i k c}$ and $g_{i k c}$ to maximize eq. [1] subject to the budget constraint $x_{i k c}+g_{i k c}=m_{i k c}$, where $m_{i k c}$ is donor i's income. Assuming an interior solution, at the optimal choice, the marginal benefit of giving derived from increasing the consumption of other group members in the donor's racial group equals the marginal cost of giving in terms of foregone private consumption:

$$
\frac{\left(1-\chi_{i k c}\right) \theta_{c}}{\omega_{c}+\sigma_{k c} g_{i k c}}=\frac{\chi_{i k c}}{m_{i k c}-g_{i k c}} .
$$

Solving eq. [2] for $g_{i k c}$, donor i's optimal choice of giving equals:

$$
g_{i k c}=\left(1-\chi_{i k c}\right) m_{i k c}-\frac{\chi_{i k c} \omega_{c}}{\theta_{c}} .
$$

Let $K_{c}$ denote the set of donors that are members of congregation $k$ in community $c$. Then, the aggregate giving for congregation $k$ in community $c$ is

$$
g_{k c} \equiv \sum_{i \in K_{c}} g_{i k c}=\sum_{i \in K_{c}}\left(1-\chi_{i k c}\right) m_{i k c}-\frac{\omega_{c}}{\theta_{c}} \sum_{i \in K_{c}} \chi_{i k c} .
$$

To further simplify expression [4] and illuminate the determinants of congregation-level giving, we let both the strength of donors' motivation for giving relative to private consumption and the donors' income be homogeneous within a congregation: $\chi_{i k c}=\chi_{k c}$ and $m_{i k c}=m_{k c}$ for all donors $i \in K_{c}$ belonging to congregation $k$ in community $c$. This captures the notion that congregations plausibly attract relatively like-minded and similarly affluent individuals, a process facilitated by competition in the religious marketplace (Iannaccone 1998), individuals' tendencies for social conformity (see, e.g., Argyle and Beit-Hallahmi

7 For analyses of free riding in the context of religious giving, see, e. g., Zaleski and Zech (1992, 1996) and Lipford (1995).

8 Ribar and Wilhelm (2002) provide evidence suggesting that, at the margin, donations to charitable organizations are motivated solely by warm-glow ("joy-of-giving”) preferences. 
1975, 117) and a high level of racial homogeneity within congregations in our sample (see Section 4). Then,

$$
g_{k c}=n_{k c}\left(\left(1-\chi_{k c}\right) m_{k c}-\frac{\chi_{k c} \omega_{c}}{\theta_{c}}\right),
$$

where $n_{k c}$ denotes the number of members of congregation $k$ in community $c$.

Expressions [4] and [5] suggest that congregation-level religious giving varies with both congregation-specific and community-level factors. In particular, congregation-level religious giving (see expression [5]) increases with the total membership of the congregation, the affluence of the congregation's members, the strength of the congregation members' preference for giving relative to private consumption and the share of the donors' racial group in the community. In contrast, congregation-level religious giving decreases with the wealth endowment of the donors' racial group in the community.

\section{Data and Variables}

To empirically test whether religious giving is motivated by racial group affinity, we draw on a thus far unexplored, restricted-access, congregation-level dataset provided to us by the SCC under consideration. Like other members of the RCC in other US states, the SCC in question annually administers a survey of congregations (SC). The SC is a voluntary survey that gathers basic financial, personnel and impact data at the congregation level. ${ }^{9}$ The SC data is not publicly available. We have been granted access to the SC data collected by the SCC under consideration for research purposes subject to a data protection agreement. Our access to the data is restricted in that we do not observe congregations' names.

The SCC we study categorizes congregations by the predominant ethnicity of the congregation members. Our sample consists of congregations (churches and a few missions) for which the members' dominant ethnicity is "White, nonHispanic" (white, in short). The SCC in question unfortunately does not collect more detailed data on racial composition of its congregations. However, both the SCC and the RCC congregations in question have a history of being highly racially segregated. Consequently, individual SCC congregations are very homogeneous in terms of their racial composition. A congregation identified as

9 Recent survey response rates have been very high, with $90 \%$ of the congregations (members of the SCC under consideration) participating in the survey. 
predominantly "White, Non-Hispanic" in our dataset is, therefore, very likely indeed nearly entirely composed of white members. White congregations represent an overwhelming majority of all SCC congregations. ${ }^{10}$

As our measure of the congregation's community, we use the county (see, e. g., Hungerman 2008). ${ }^{11}$ We thus combine our congregation-level data with county-level Census demographic and socioeconomic data for the state under consideration as well as county-level data on the number of churches and their adherents across different denominations collected by the RCMS. Because our main explanatory variable of interest, the share of whites in a county in a given year, is measured by the Census on a decennial basis, we only use four cross sections of our congregation-level data: years 1980, 1990, 2000 and 2010. We first drop observations with unclear or evidently erroneous records and observations that involve missing values for a number of variables. In order to focus on active congregations we further drop congregation-year observations that report five or fewer resident members in a given year. ${ }^{12}$ Our final dataset consists of a maximum of 4,623 congregation-year observations. As we clarify in Section 6.7, appropriate tests suggest that the unbalanced nature of our panel does not give rise to sample selection issues. Table 1 defines and describes the variables used in our analysis.

To measure religious giving, we use the total value of receipts collected by a congregation in a given county in a given year. ${ }^{13}$ Given our focus on white congregations, our key explanatory variable is the percent of the population self-reported as white, non-Hispanic, in a given year in the county where the congregation is located. Our primary congregation-level control is resident membership. Resident membership controls for the effect of congregation size. It is also a good proxy for religious attendance, which captures aspects of religiosity that might affect giving. For example, high church attendance signals religious commitment, which may in turn affect religious giving (Lincoln, Morrissey, and Mundey 2008, 7). Furthermore, higher attendance exposes people to more charitable solicitation, which might in itself drive giving

10 The presence of racial-group affinity effects in religious giving could in principle also be tested using non-white congregations. However, the number of non-white congregations in our dataset is very small and, hence, does not lend itself to econometric analysis.

11 Due to a combination of the lack of compatibility of census tract definitions across the four decades of our interest (1980-2010) and the imprecise information on geo-locations of our congregations, the use of the census tract as an alternative measure of congregation's community is not feasible.

12 None of our results change if we set the threshold for the minimum number of resident members and Sunday school attendance at a higher or a lower value.

13 Congregations in our sample do not change counties during the time period of our analysis. 
Table 1: Variable definitions.

\begin{tabular}{|c|c|c|}
\hline Variable name & Variable description & Source \\
\hline \multicolumn{3}{|l|}{ Panel A: Main variables } \\
\hline \multicolumn{3}{|l|}{ Congregation level } \\
\hline Total receipts & $\begin{array}{l}\text { Total amount of money donated to the } \\
\text { congregation in a given year, in USD }\end{array}$ & SCC SC \\
\hline Resident membership & $\begin{array}{l}\text { Total active membership of the congregation } \\
\text { in a given year }\end{array}$ & SCC SC \\
\hline $\begin{array}{l}\text { Sunday school } \\
\text { attendance }\end{array}$ & $\begin{array}{l}\text { Average number of members } 25 \text { years or older } \\
\text { that attend Sunday school }\end{array}$ & SCC SC \\
\hline \multicolumn{3}{|l|}{ County level } \\
\hline$\%$ White & Percent of white residents in the county & $\begin{array}{l}\text { Decennial Census } \\
1980-2010\end{array}$ \\
\hline Median income & $\begin{array}{l}\text { Median family income in the county, } \\
\text { in } 1,000 \text { USD }\end{array}$ & $\begin{array}{l}\text { Decennial Census } \\
1980-2010\end{array}$ \\
\hline$\%$ Families in poverty & $\begin{array}{l}\text { Percent of families below the poverty line } \\
\text { in the county }\end{array}$ & $\begin{array}{l}\text { Decennial Census } \\
1980-2010\end{array}$ \\
\hline$\%$ College degree & $\begin{array}{l}\text { Percent of county residents who have completed } \\
\text { some college or more }\end{array}$ & $\begin{array}{l}\text { Decennial Census } \\
\text { 1980-2010 }\end{array}$ \\
\hline Population density & $\begin{array}{l}\text { Total county population divided by county area } \\
\text { in square miles }\end{array}$ & $\begin{array}{l}\text { Decennial Census } \\
1980-2010\end{array}$ \\
\hline Religious Diversity Index & $\begin{array}{l}\text { Sum across denominations of the squared } \\
\text { shares of churches of a given denomination }\end{array}$ & $\begin{array}{l}\text { Computed using } \\
\text { RCMS }\end{array}$ \\
\hline \multicolumn{3}{|c|}{ Panel B: Additional congregation-level variables } \\
\hline $\begin{array}{l}\text { Total receipts per } \\
\text { resident member }\end{array}$ & $\begin{array}{l}\text { Ratio of total amount of money donated } \\
\text { to the congregation in a given year (in USD) } \\
\text { to total active membership }\end{array}$ & $\begin{array}{l}\text { Computed using } \\
\text { SCC SC }\end{array}$ \\
\hline $\begin{array}{l}\text { Sunday school } \\
\text { attendance per resident } \\
\text { member }\end{array}$ & $\begin{array}{l}\text { Ratio of average number of members } 25 \text { years } \\
\text { or older that attend Sunday school to total } \\
\text { active membership }\end{array}$ & $\begin{array}{l}\text { Computed using } \\
\text { SCC SC }\end{array}$ \\
\hline Local missionaries & $\begin{array}{l}\text { Number of congregation members who } \\
\text { participated in local missions (projects } \\
\text { in local area) }\end{array}$ & SCC SC \\
\hline Share local missionaries & $\begin{array}{l}\text { Ratio of number of congregation members who } \\
\text { participated in local missions (projects in local } \\
\text { areas) to number of congregation members who } \\
\text { participated in any missions }\end{array}$ & $\begin{array}{l}\text { Computed using } \\
\text { SCC SC }\end{array}$ \\
\hline
\end{tabular}

Notes: SCC SC stands for the state-level congregational convention's survey of congregations (see Section 4). RCMS stands for Religious Congregations and Membership Study. 
(Lincoln, Morrissey, and Mundey 2008, 8). In robustness checks (see Section 6.1), we include a further congregation-level measure of religiosity and attendance.

Two further congregation-level variables that should influence church giving based on our theoretical framework (see Section 3) - the affluence of church membership and the members' innate preference for giving - are unobservable to us. To address a likely omitted variable bias due to this unobserved congregationlevel heterogeneity, our preferred estimated models (discussed in detail in the following section) include congregation fixed effects as well as congregationspecific time trend (see Sections 5.2 and 5.3).

Our primary proxy for wealth endowment of the gift recipient population is median income in the county. In performing robustness checks (see Section 6), we also control for county-level percent of families under the poverty line, educational attainment and population density. Following the literature emphasizing the importance of religious competition on church activity and giving (see, e.g., Zaleski and Zech 1995, Coate and Vanderhoff 2009), we further include a measure of county-level religious diversity.

Panel A of Tables 2 and 13 shows the key descriptive statistics for the full sample. (In parts of our analysis, we further distinguish between congregations located in urban versus rural counties; we discuss this categorization and the associated results in the sensitivity analysis in Section 6.3.) Table 11 shows the descriptive statistics by year. The average percent of whites in the county gradually but steadily decreased between 1980 and 2010, while the average median county income and average total receipts collected by congregations increased in both nominal and real terms (taking into account the approximately 2.6-fold increase in the price level between 1980 and 2010 as measured by the Consumer Price Index). In line with the background information on the SCC under consideration provided in Section 2, average congregational resident membership and Sunday school attendance decreased between 2000 and 2010. Table 13 shows descriptive statistics for additional variables used in various robustness checks (see Section 6).

Finally, we note that an important part of empirically observed variation in charitable giving may be explained by differences in marginal tax rates across jurisdictions (see, e. g., Andreoni 2006, 2008; Vanderhoff 2012, Yörük 2013). Our exclusive focus on the congregations belonging to the given SCC directly addresses this issue since individual income tax rates, which affect the price of charitable giving, are determined at the state level and, hence, do not vary across counties within US states. Moreover, the state in question does not allow for the collection of municipal- and county-level income taxes that would otherwise add to the complexity of the tax structure. 
Table 2: Summary statistics, main variables.

\begin{tabular}{|c|c|c|c|c|c|}
\hline Variable name & No. obs. & Mean & Std. dev. & Min. & Max. \\
\hline \multicolumn{6}{|l|}{ Panel A: Full sample } \\
\hline \multicolumn{6}{|l|}{ Congregation level } \\
\hline Total receipts (in USD) & 4,623 & $196,895.3$ & $551,250.2$ & 75.0 & $14,308,447.0$ \\
\hline Resident membership & 4,623 & 300.4 & 437.6 & 7 & 5,569 \\
\hline Sunday school attendance & 4,623 & 110.3 & 207.3 & 6 & 3,156 \\
\hline \multicolumn{6}{|l|}{ County level } \\
\hline$\%$ White & 229 & 67.7 & 13.3 & 28.1 & 95.7 \\
\hline Median income (in USD) & 229 & $25,152.6$ & $11,325.3$ & $7,780.0$ & $60,874.0$ \\
\hline$\%$ Families in poverty & 229 & 18.8 & 6.6 & 7.2 & 51.2 \\
\hline$\%$ College degree & 229 & 10.5 & 4.1 & 2.7 & 20.2 \\
\hline Population density & 229 & 139.9 & 345.6 & 5.2 & $3,087.0$ \\
\hline Religious Diversity Index & 229 & 0.230 & 0.109 & 0.034 & 0.662 \\
\hline \multicolumn{6}{|l|}{ Panel B: Urban sample } \\
\hline \multicolumn{6}{|l|}{ Congregation level } \\
\hline Total receipts (in USD) & 1,980 & $322,922.0$ & $800,290.3$ & 75.0 & $14,308,447.0$ \\
\hline Resident membership & 1,980 & 438.4 & 606.5 & 9 & 5,569 \\
\hline Sunday school attendance & 1,980 & 167.1 & 291.1 & 6 & 3,156 \\
\hline \multicolumn{6}{|l|}{ County level } \\
\hline$\%$ White & 94 & 69.0 & 14.5 & 28.1 & 95.7 \\
\hline Median income (in USD) & 94 & $29,803.5$ & $12,074.8$ & $11,300.0$ & $60,874.0$ \\
\hline$\%$ Families in poverty & 94 & 14.7 & 4.6 & 7.2 & 32.5 \\
\hline \% College degree & 94 & 11.9 & 4.4 & 3.1 & 20.1 \\
\hline Population density & 94 & 285.0 & 520.6 & 5.2 & $3,087.0$ \\
\hline Religious Diversity Index & 94 & 0.188 & 0.108 & 0.034 & 0.662 \\
\hline \multicolumn{6}{|l|}{ Panel C: Rural sample } \\
\hline \multicolumn{6}{|l|}{ Congregation level } \\
\hline Total receipts (in USD) & 2,643 & $102,482.6$ & $176,207.9$ & 961.0 & $2,952,675.0$ \\
\hline Resident membership & 2,643 & 196.9 & 185.7 & 7 & 1,645 \\
\hline Sunday school attendance & 2,643 & 67.8 & 86.5 & 6 & 1,365 \\
\hline \multicolumn{6}{|l|}{ County level } \\
\hline$\%$ White & 135 & 66.3 & 13.4 & 28.9 & 94.1 \\
\hline Median income (in USD) & 135 & $21,038.3$ & $9,085.6$ & $7,780.0$ & $43,441.0$ \\
\hline$\%$ Families in poverty & 135 & 22.0 & 6.4 & 10.1 & 51.2 \\
\hline$\%$ College degree & 135 & 9.2 & 3.5 & 2.7 & 16.5 \\
\hline Population density & 135 & 41.0 & 27.1 & 7.1 & 153.2 \\
\hline Religious Diversity Index & 135 & 0.257 & 0.100 & 0.068 & 0.465 \\
\hline
\end{tabular}

Notes: The table reports summary statistics for the samples used to generate the results in Tables 3 and 4. 


\section{Empirical Strategy and Baseline Results}

Based on the theoretical framework developed in Section 3, we specify the following general empirical model to be estimated using a panel of predominantly white SCC congregations:

$$
\text { Total Receipts } k_{k t}=f\left(\% \text { White }_{c t}, X_{k c t}, Z_{c t}\right)+u_{k c t}
$$

In eq. [6], subscript $k$ identifies congregation, $c$ county and $t$ year. The outcome variable Total Receipts kct $_{\text {is }}$ logged total receipts from charitable giving in congregation $k$ located in county $c$ in year $t$. Our focal explanatory variable $\%$ White $_{c t}$ is the percent of residents self-identified as white in county $c$ in year $t$. $X_{k c t}$ is a vector of congregation-level controls. $Z_{c t}$ is a vector of county-level controls. $u_{k c t}$ is the error term.

Using variants of model [6], we explore several empirical approaches to estimate the effect of racial group affinity on religious giving. For all of the regression models we estimate, we base inference on heteroskedasticity-robust standard errors clustered at the county level. Clustering of errors at the county level allows us to correct for plausible correlation of the error terms over time for all congregations within a given county (but we rule out correlation between error terms across counties).

\subsection{Benchmark: Naïve Pooled OLS}

As a benchmark, we examine the association between the percent of whites in the county and religious giving by estimating the following model:

$$
\text { Total Receipts } \text { Rct }=\alpha+\beta \times \% \text { white }_{c t}+X_{k c t}{ }^{\prime} \gamma+Z_{c t}{ }^{\prime} \delta+\lambda_{t}+u_{k c t},
$$

where the variables Total Receipts ${ }_{k c t}$, \%White $c t$ and the vectors $X_{k c t}$ and $Z_{c t}$ are defined earlier. $\alpha$ is the regression constant. $\lambda_{t}$ is a year fixed effect included to control for any business cycle effects and state-level changes in institutional environment (including taxation), as well as to facilitate the interpretation of the effects of our explanatory variables on congregation-level total receipts as real (as opposed to nominal).

We estimate model [7] using pooled OLS. The results are reported in columns (1) and (2) of Table 3. The association between the percent of whites in the county and congregation's total receipts is negative and statistically significant both when we control only for congregation's resident membership and year fixed effects (column (1)) as well as when we additionally control for the median 
Table 3: Baseline results, full sample.

\begin{tabular}{|c|c|c|c|c|c|}
\hline \multirow[t]{2}{*}{ Explanatory variables } & \multicolumn{2}{|r|}{ Pooled OLS } & \multicolumn{2}{|r|}{ FE } & \multirow{2}{*}{$\frac{\mathrm{FE}-\mathrm{IV} / 2 \mathrm{SLS}}{(5)}$} \\
\hline & (1) & (2) & (3) & (4) & \\
\hline \% White (in county) & $\begin{array}{l}-0.0060^{\star \star *} \\
(0.0015)\end{array}$ & $\begin{array}{l}-0.0088^{\star \star \star} \\
(0.0018)\end{array}$ & $\begin{array}{l}0.0100^{\star \star} \\
(0.0047)\end{array}$ & $\begin{array}{l}0.0106^{\star \star} \\
(0.0047)\end{array}$ & $\begin{array}{l}0.0266^{\star \star \star} \\
(0.0095)\end{array}$ \\
\hline \multicolumn{6}{|l|}{ Congregation level } \\
\hline Log Resident membership & $\begin{array}{l}1.051^{\star \star *} \\
(0.0162)\end{array}$ & $\begin{array}{l}1.0310^{\star \star \star *} \\
(0.0163)\end{array}$ & $\begin{array}{l}0.6010^{\star \star \star} \\
(0.0207)\end{array}$ & $\begin{array}{l}0.5600^{\star \star \star} \\
(0.0203)\end{array}$ & $\begin{array}{l}0.5345^{\star \star \star *} \\
(0.0254)\end{array}$ \\
\hline \multicolumn{6}{|l|}{ County level } \\
\hline $\begin{array}{l}\text { Median income } \\
\text { (in USD } 1,000 \text { ) }\end{array}$ & & $\begin{array}{l}0.0155^{\star \star \star} \\
(0.0038)\end{array}$ & $\begin{array}{r}0.0057 \\
(0.0044)\end{array}$ & $\begin{array}{r}0.0062 \\
(0.0042)\end{array}$ & $\begin{array}{r}0.0013 \\
(0.0048)\end{array}$ \\
\hline Year FE & Yes & Yes & Yes & Yes & Yes \\
\hline Congregation FE & No & No & Yes & Yes & Yes \\
\hline Congregation time trend & No & No & No & Yes & Yes \\
\hline$R^{2}$ & 0.7812 & 0.7844 & 0.9181 & 0.9182 & - \\
\hline No. obs. & 4,623 & 4,623 & 4,623 & 4,623 & 3,278 \\
\hline
\end{tabular}

Notes: Full sample. The dependent variable is log total receipts (measured at congregation level). Models (1) and (2) are estimated using pooled ordinary least squares (OLS). Models (3) and (4) are estimated using fixed effects (FE) "within" estimator. Model (5) is estimated using fixed effects instrumental variable/two-stage least squares (FE-IV/2SLS) approach, where the instrument for \% White is its decennial lag; see Table 12 for first-stage results. Heteroskedasticityrobust standard errors clustered at the county level in parentheses. ${ }^{\star \star \star}$, ** and * indicate statistical significance at the $1 \%, 5 \%$ and $10 \%$ levels, respectively.

family income in the county (column (2)). ${ }^{14}$ Based on the estimates in column (2), a 1 percentage point decrease in the percent of whites in the community (i. e., county) is, in contrast with the predictions of our theoretical framework, ceteris paribus associated with a $0.88 \%$ increase in congregation's total receipts.

To interpret the pooled OLS estimate of $\beta$ from expression [7] in column (2) of Table 3 as the causal effect of the percent of white in the county on total congregation receipts, our congregation-level and county-level controls must adequately control for all possible factors that are correlated with the percent of whites in the county and, at the same time, total receipts. That is, to establish causality, the error term $u_{k c t}$ in eq. [7] must be uncorrelated with the variable \% White $_{c t}$. This is a strong and likely untenable assumption, in particular since

14 The correlation coefficient between the percent of whites and median family income in the county equals 0.0353 . Thus, we can rule out any concerns that our results are perhaps driven by multicollinearity between these variables. 
data availability precludes us from adequately controlling for congregation-level differences in the strength of congregation members' preference for giving relative to private consumption and the affluence of congregation members (see Section 3). As a result, the pooled OLS estimates of $\beta$ discussed earlier are likely biased. To better address endogeneity concerns, we turn to estimation of fixed effects specifications.

\subsection{Fixed Effects Specifications}

We explore two fixed effects specifications:

$$
\begin{gathered}
\text { Total Receipts } \text { Rct }=\beta \times \% \text { White }_{c t}+X_{k c t}{ }^{\prime} \gamma+Z_{c t}{ }^{\prime} \delta+\lambda_{t}+\mu_{k c}+v_{k c t}, \\
\text { Total Receipts }{ }_{k c t}=\beta \times \% \text { White }_{c t}+X_{k c t}{ }^{\prime} \gamma+Z_{c t}{ }^{\prime} \delta+\lambda_{t}+\mu_{k c}+\mu_{k c} t+\varepsilon_{k c t} .
\end{gathered}
$$

The crucial difference between eqs [7] and [8a] is that the latter, unlike the former, decomposes the error term into a time-invariant component $\mu_{k c}$ and a time-varying component $v_{k c t} \cdot \mu_{k c}$ is the congregation fixed effect and captures all congregation-level, time-invariant unobserved factors that may affect religious giving. An example may be the overall strength of the congregation members' preference for giving relative to private consumption. Because congregations do not change their respective residing counties during the period of our analysis, congregation fixed effects also absorb all county-level time-invariant factors that may impact religious giving.

In contrast to specification [8a], specification [8b] further decomposes the error term by including the congregation-specific linear time trend $\mu_{k c} t$ that captures any unobserved congregation- and county-specific trends that may affect religious giving. For instance, under the white flight scenario (Hungerman 2008), an increase over time in racial diversity in the county induces out-of-county relocation of the most affluent white congregation members, which in turn leads to an overall decrease in religious giving. In this case, we would observe a positive correlation between congregation-level total receipts and the percent of whites in the county regardless of whether congregation members exhibit racialgroup affinity in religious giving. In the absence of adequate proxies for wealth of congregation members, the inclusion of the congregation-specific linear time trend $\mu_{k c} t$ in eq. [8b] captures, at least in part, such congregation- and countyspecific changes. Under a tenable assumption that any changes over time in the composition of the congregation's membership do not alter the congregation-level average preference for religious giving relative to private consumption, the inclusion of congregation-specific linear time trend thus mitigates the concern that any association between the county-level percent of whites and total receipts in the 
predominantly white congregations should be attributed to white flight rather than racial group affinity. In the robustness checks (see Section 6.5), we also report results that further assure us that our results are not driven by the white flight phenomenon.

We estimate the fixed effects models [8a] and [8b] using the fixed effect "within" estimation whereby one first time demeans the data (to eliminate the congregation fixed effect) and then estimates the resulting time-demeaned model with OLS. ${ }^{15}$ Columns (3) and (4) in Table 3 present the results. Both specifications in columns (3) and (4) control for the congregation's resident membership and median income in the county. Unlike the specification in column (3), the specification in column (4) also controls for the congregationspecific linear time trend. In contrast with the pooled OLS estimates in columns (1) and (2), and consistent with our theoretical predictions, the fixed effect estimates suggest there is a statistically significant positive association between the percent of whites in the community and congregation's total receipts. As anticipated, controlling for congregation-level unobserved heterogeneity is therefore important. Based on the estimates in column (4), a 1 percentage point decrease in the percent of whites in the county is associated with about $1.1 \%$ decrease in congregation's total receipts. While the coefficient on logged resident membership remains positive and statistically significant, the coefficient on median family income in the county loses statistical significance once we control for congregation-level fixed effects (compare columns (3) and (2)).

\subsection{Approach}

In a further attempt to address endogeneity concerns in assessing the effect of the percent of whites in a county on religious giving, we combine fixed effects estimation with an IV approach. Finding a suitable instrument for the percent of whites in a county is challenging. To this end, our instrumentation strategy closely follows the existing literature that has examined the socioeconomic effects of a community's racial composition. Alesina, Baqir, and Easterly (1999, 1261) instrument for their current measure of country's ethnic fragmentation using past values of this measure. Similarly, Hungerman (2008, 388) instruments for the current share of black population in the community with the share of black population lagged by ten years. We therefore propose the decennial lag

15 This approach is equivalent to least squares dummy variable (LSDV) estimation where models [8a] and [8b] are estimated using OLS directly upon the inclusion of a full set of congregation-specific dummies (see, e. g., Wooldridge 2002). 
of the percent of whites in a county as an instrument for the current percent of whites in the county. Given that racial composition of a geographic area typically does not change abruptly, we expect that the ten-year lagged value of the share of whites is highly correlated with the current share of whites in the county. At the same time, the share of whites in the county ten years ago is unlikely to directly influence religious giving today, especially once controlling for a range of time-varying congregation-level and county-level factors, as well as congregation fixed effects. That is, we argue that the ten-year lag of percent of whites in the county plausibly satisfies the exclusion restriction and provides for an adequate source of exogenous variation in the current share of whites in a county. ${ }^{16}$

We estimate model [8b] using the fixed effects instrumental variable/twostage least squares (FE-IV/2SLS) estimator, where the variable $\% W_{h i t e}$ is instrumented for with its ten-year lag. The second-stage results are presented in column (5) of Table 3. The estimated effect of the percent of whites in the county on congregation's total receipts is statistically significant (at 1\% significance level) and more than twice the size of the fixed effects estimates in columns (3) and (4). Thus, addressing endogeneity concerns through the application of an IV approach is quantitatively important. Simple fixed effects estimates are downward biased. Based on the estimates in column (5), a 1 percentage point decrease in the percent of whites in the county decreases the congregation's total receipts by $2.7 \%$.

The corresponding first-stage regression results are shown in the first column of Table 12 in the Appendix. As conjectured, we find the ten-year lagged percent of whites in the county to be a statistically very significant predictor of the current percent of whites in the county. Ceteris paribus, the current percent of whites in the county is strongly positively associated with the percent of whites in the county ten years ago. The large value of the test statistic for the $F$ test of excluded instruments (27.5) notably exceeds the rule-of-thumb threshold value of ten (see, e. g., Staiger and Stock 1997) below which an instrument is considered "weak". ${ }^{17}$

16 As an alternative IV we explored a measure of the extent of community law enforcement institutions' racial bias against non-whites, which in turn plausibly affects the racial composition of a community. Our results (available upon request) using this alternative IV resonated with our findings reported in Sections 5.3, 6.3 and 6.4 when it comes to the sign of the estimated effect of percent whites on religious giving. First-stage results using this alternative IV, however, were weak.

17 See Stock and Yogo (2005) for a more precise analysis of criteria for the relative weakness of instruments. 


\section{Sensitivity Analysis and Further Results}

\subsection{Additional Controls}

We subject our results to a battery of robustness checks and alternative specifications. We first examine the robustness of our fixed effect results (columns (3) and (4) in Table 3) to inclusion of congregation-level variables that plausibly affects religious giving and in addition may correlate with the percent of whites in the county. One such variable is religiosity. We use average Sunday school attendance as our measure of religiosity. ${ }^{18}$ The results in column (1) of Table 4, which feature a full set of congregation fixed effects and congregation-specific time trend, show that while total receipts are ceteris paribus indeed positively associated with logged Sunday school attendance, the coefficient on percent whites in the county remains positive, statistically significant and in terms of magnitude very similar to the estimates in columns (3) and (4) of Table 3.

While continuing to control for the extent of congregation-level religiosity, we next introduce additional county-level controls to further isolate the effect of percent whites in the county from the potentially confounding effect of other county-level variables. In column (2) of Table 4, we add a measure of the percent of families in the county that are below the poverty line. In column (3), we further add a measure of educational attainment in the county and also control for population density. None of these additional county-level variables are statistically significant. At the same time, the coefficient on percent whites in the county remains positive, statistically significant and virtually unchanged in terms of magnitude.

We next add a Herfindahl-Hirschman index of county-level religious diversity to control for effects of religious competition on church giving. By construction, higher values of the index imply lower religious diversity (see Table 1). Greater religious diversity may induce stronger competition for members and lead to intensified fund-raising at the level of congregations (see, e. g., Finke and Stark 1988; Zaleski and Zech 1995; Coate and Vanderhoff 2009). Religious diversity may also influence an area's racial composition. Albeit statistically insignificant, the coefficient on the religious diversity index in column (4) of Table 4 is negative, suggesting that total receipts ceteris paribus indeed increase with greater religious diversity. The coefficient on percent whites in the county remains positive, statistically significant and virtually unchanged in size.

18 A further proxy for religiosity in our data, average worship attendance, is reported very inconsistently prior to year 2000. We therefore do not utilize this variable in our analysis. 
Table 4: Robustness checks, full sample, additional controls.

\begin{tabular}{|c|c|c|c|c|c|}
\hline \multirow[t]{2}{*}{ Explanatory variables } & \multicolumn{4}{|r|}{$\mathrm{FE}$} & \multirow{2}{*}{$\frac{\mathrm{FE}-\mathrm{IV} / 2 \mathrm{SLS}}{(5)}$} \\
\hline & (1) & (2) & (3) & (4) & \\
\hline$\%$ White (in county) & $\begin{array}{l}0.0099^{* *} \\
(0.0043)\end{array}$ & $\begin{array}{l}0.0097^{\star *} \\
(0.0045)\end{array}$ & $\begin{array}{l}0.0092^{\star \star} \\
(0.0044)\end{array}$ & $\begin{array}{l}0.0092^{\star \star} \\
(0.0045)\end{array}$ & $\begin{array}{l}0.0249^{\star \star \star} \\
(0.0092)\end{array}$ \\
\hline \multicolumn{6}{|l|}{ Congregation level } \\
\hline Log Resident membership & $\begin{array}{l}0.3295^{\star \star \star} \\
(0.0219)\end{array}$ & $\begin{array}{l}0.3296^{\star \star \star} \\
(0.0219)\end{array}$ & $\begin{array}{l}0.3303^{\star * \star} \\
(0.0219)\end{array}$ & $\begin{array}{l}0.3302^{\star \star \star} \\
(0.0220)\end{array}$ & $\begin{array}{l}0.2896^{\star \star \star} \\
(0.0220)\end{array}$ \\
\hline $\begin{array}{l}\text { Log Sunday school } \\
\text { attendance }\end{array}$ & $\begin{array}{l}0.4636^{\star \star \star} \\
(0.0300)\end{array}$ & $\begin{array}{l}0.4636^{\star \star \star} \\
(0.0300)\end{array}$ & $\begin{array}{l}0.4633^{\star \star \star} \\
(0.0299)\end{array}$ & $\begin{array}{l}0.4633^{\star \star \star} \\
(0.0299)\end{array}$ & $\begin{array}{l}0.4952^{\star \star \star} \\
(0.0373)\end{array}$ \\
\hline \multicolumn{6}{|l|}{ County level } \\
\hline $\begin{array}{l}\text { Median income (in USD } \\
1,000 \text { ) }\end{array}$ & $\begin{array}{r}0.0018 \\
(0.0034)\end{array}$ & $\begin{array}{r}0.0016 \\
(0.0034)\end{array}$ & $\begin{array}{r}0.0011 \\
(0.0038)\end{array}$ & $\begin{array}{r}0.0011 \\
(0.0038)\end{array}$ & $\begin{array}{l}-0.0015 \\
(0.0044)\end{array}$ \\
\hline$\%$ Families in poverty & & $\begin{array}{l}-0.0009 \\
(0.0041)\end{array}$ & $\begin{array}{l}-0.0006 \\
(0.0041)\end{array}$ & $\begin{array}{l}-0.0006 \\
(0.0041)\end{array}$ & $\begin{array}{r}0.0009 \\
(0.0059)\end{array}$ \\
\hline$\%$ College degree & & & $\begin{array}{r}0.0066 \\
(0.0100)\end{array}$ & $\begin{array}{r}0.0066 \\
(0.0099)\end{array}$ & $\begin{array}{l}-0.0069 \\
(0.0147)\end{array}$ \\
\hline Population density & & & $\begin{array}{l}-0.0001 \\
(0.0001)\end{array}$ & $\begin{array}{l}-0.0001 \\
(0.0001)\end{array}$ & $\begin{array}{r}0.0001 \\
(0.0002)\end{array}$ \\
\hline Religious Diversity Index & & & & $\begin{array}{l}-0.0549 \\
(0.3164)\end{array}$ & $\begin{array}{r}0.1229 \\
(0.4277)\end{array}$ \\
\hline Year FE & Yes & Yes & Yes & Yes & Yes \\
\hline Congregation FE & Yes & Yes & Yes & Yes & Yes \\
\hline Congregation time trend & Yes & Yes & Yes & Yes & Yes \\
\hline$R^{2}$ & 0.9294 & 0.9294 & 0.9295 & 0.9295 & - \\
\hline No. obs. & 4,623 & 4,623 & 4,623 & 4,623 & 3,278 \\
\hline
\end{tabular}

Notes: Full sample. The dependent variable is log total receipts (measured at congregation level). Models (1)-(4) are estimated using fixed effects (FE) "within" estimator. Model (5) is estimated using fixed effects instrumental variable/two-stage least squares (FE-IV/2SLS) approach, where the instrument for \% White is its decennial lag; see Table 12 for first-stage results. Heteroskedasticity-robust standard errors clustered at the county level in parentheses. ***, ** and * indicate statistical significance at the $1 \%, 5 \%$ and $10 \%$ levels, respectively.

We apply the fixed effects IV approach, laid out in Section 5.3, to the specification with the maximum number of congregation-level and county-level controls featured in column (4) of Table 4. Column (5) of Table 4 presents the secondstage regression results. The estimate of the coefficient on the percent of whites in the county is positive, statistically very significant and very similar in magnitude to the corresponding estimate reported in column (5) of Table 3. The associated first-stage results (second column of Table 12 in the Appendix) 
again show that the ten-year lagged percent of whites in the county is a statistically very significant predictor of the current percent of whites in the county. The value of the test statistic for the $F$-test of excluded instruments (45.7) again notably exceeds the Staiger and Stock (1997) rule-of-thumb value of ten.

\subsection{More vs. Less Segregated Communities}

We examine if the presence and strength of the racial group affinity bias in religious giving depends on the characteristics of the community. The importance of racial group affinity may vary depending on how residentially racially segregated a community is because the extent of residential racial segregation shapes the immediate opportunities for intergroup contact. For example, it is plausible that in residentially racially more segregated communities the prevalence of racial in-group bias would be greater than in residentially racially less segregated communities where there are more immediate opportunities for interaction between people of different races and ethnicities and, therefore, where any prejudice against out-groups is less likely to be perpetuated (see, e. g., Pettigrew and Tropp 2006). Alternatively, under adverse conditions, more frequent contact between different racial or ethnic groups in residentially less segregated communities has the potential to breed "suspicion, fear, resentment" (Pettigrew and Tropp 2006, 751), which would tend to strengthen any racial in-group bias.

To explore these hypotheses empirically in our context, we designate counties as more versus less racially residentially segregated based on the measure of racial residential segregation ("index of dissimilarity") developed by the University of Michigan's Population Studies Center. ${ }^{19}$ This measure determines the evenness with which whites and blacks (as the predominant non-white racial group in the state under consideration) are distributed across Census tracts in a county. The maximum possible value of 100 corresponds to full segregation. The minimum possible value of 0 captures a scenario where races are evenly distributed across Census tracts in a county. Higher values of the index therefore correspond to greater residential segregation of whites and blacks in the community.

The racial segregation index we use was constructed using the 2000 Census data. Because the patterns of residential racial segregation are bound to change over time (see, e. g., Cutler, Glaeser, and Vigdor 1999), a measure of segregation based on 2000 Census is unlikely going to be accurate for more than a decade before or after year 2000. In this part of the analysis, we therefore drop the 1980

19 See http://enceladus.isr.umich.edu/race/seg.html. 
cross section of observations. Due to massive within-state relocations, induced by a major natural disaster that impacted the state in the first decade of the new millennium, we also drop the 2010 cross section of observations. We then compute the median value of the segregation index for the remaining 1990 and 2000 congregation-year observations (the median value equals 45) and stratify the sample based on whether the observations are associated with higher than this median value (high segregation sample) or lower than this median value (low segregation sample). ${ }^{20}$

Table 5 summarizes the results for the two samples using fixed effects specification featuring the maximum number of congregation-level and county-level controls (as featured in column (4) of Table 4) as well as fixed effects IV approach (as featured in column (5) of Table 4). We find that the effect of percent of whites on religious giving is positive and statistically significant in both the high segregation sample (columns (1) and (2)) and in the low segregation sample (columns (3) and (4)). Based on the IV estimates (columns (2) and (4)), a $1 \%$ decrease in the percent of whites all else equal decreases religious giving by only slightly more in the high segregation sample than in the low segregation sample. That is, based on our results, the extent of racial residential segregation of a community per se does not appear to matter much for the magnitude of the effect of the percent of whites in the community on religious giving.

\subsection{Urban versus Rural Communities}

We next examine the role played by a further community characteristic: urban versus rural status. The literature provides evidence that cooperative behavior sometimes varies with the community's urban versus rural status (see, e.g., Gächter and Herrmann 2011). It is possible, therefore, that the presence and strength of racial group affinity in religious giving depends on whether a community is urban or rural. On the one hand, relative to rural communities, the larger urban communities allow for more opportunities for individuals to interact with individuals of different races and ethnic groups, which, as noted in Section 6.2, plausibly weakens any preferences for one's own racial group. On the other hand, in contrast to the relatively more close-knit rural communities, the generally greater size and heterogeneity of social networks in urban communities (see, e. g., Marsden 1987) also allows the individuals, if they choose so,

20 To economize on space, we do not report separate descriptive statistics for the two samples. 
Table 5: Results, more versus less residentially racially segregated communities.

\begin{tabular}{|c|c|c|c|c|}
\hline \multirow[b]{2}{*}{ Explanatory variables } & \multicolumn{2}{|c|}{ High segregation } & \multicolumn{2}{|c|}{ Low segregation } \\
\hline & (1) FE & $\begin{array}{r}\text { (2) } \mathrm{FE}-\mathrm{IV} / \\
2 \mathrm{SLS}\end{array}$ & (3) FE & $\begin{array}{r}\text { (4) } \mathrm{FE}-\mathrm{IV} / \\
2 \mathrm{SLS}\end{array}$ \\
\hline \% White (in county) & $\begin{array}{l}0.0181^{+} \\
(0.0128)\end{array}$ & $\begin{array}{l}0.0769^{\star \star} \\
(0.0295)\end{array}$ & $\begin{array}{l}0.0194^{*} \\
(0.0104)\end{array}$ & $\begin{array}{l}0.0702^{\star \star \star} \\
(0.0204)\end{array}$ \\
\hline \multicolumn{5}{|l|}{ Congregation level } \\
\hline Log Resident membership & $\begin{array}{l}0.3339 * \star \star \\
(0.0628)\end{array}$ & $\begin{array}{l}0.3055^{\star \star \star} \\
(0.0556)\end{array}$ & $\begin{array}{l}0.3111^{\star * *} \\
(0.0635)\end{array}$ & $\begin{array}{l}0.3037^{\star \star \star} \\
(0.0734)\end{array}$ \\
\hline $\begin{array}{l}\text { Log Sunday school } \\
\text { attendance }\end{array}$ & $\begin{array}{l}0.4038^{\star \star \star} \\
(0.0815)\end{array}$ & $\begin{array}{l}0.4327^{\star \star \star} \\
(0.0890)\end{array}$ & $\begin{array}{l}0.4610^{\star \star \star} \\
(0.0558)\end{array}$ & $\begin{array}{l}0.4546^{\star \star \star} \\
(0.0587)\end{array}$ \\
\hline \multicolumn{5}{|l|}{ County level } \\
\hline $\begin{array}{l}\text { Median income (in USD } \\
1,000 \text { ) }\end{array}$ & $\begin{array}{l}-0.0119 \\
(0.0155)\end{array}$ & $\begin{array}{l}-0.0693 \\
(0.0429)\end{array}$ & $\begin{array}{r}0.0163 \\
(0.0106)\end{array}$ & $\begin{array}{r}0.0024 \\
(0.0116)\end{array}$ \\
\hline$\%$ Families in poverty & $\begin{array}{l}-0.0100 \\
(0.0171)\end{array}$ & $\begin{array}{l}-0.0042 \\
(0.0185)\end{array}$ & $\begin{array}{l}-0.0310^{\star \star *} \\
(0.0111)\end{array}$ & $\begin{array}{l}-0.0306^{\star \star \star} \\
(0.0103)\end{array}$ \\
\hline$\%$ College degree & $\begin{array}{l}-0.0095 \\
(0.0382)\end{array}$ & $\begin{array}{l}-0.0090 \\
(0.0368)\end{array}$ & $\begin{array}{r}0.0501 \\
(0.0309)\end{array}$ & $\begin{array}{l}0.0643^{\star} \\
(0.0300)\end{array}$ \\
\hline Population density & $\begin{array}{l}-0.0005 \\
(0.0007)\end{array}$ & $\begin{array}{r}0.0017 \\
(0.0013)\end{array}$ & $\begin{array}{l}-0.0071 \\
(0.0047)\end{array}$ & $\begin{array}{l}-0.0031 \\
(0.0045)\end{array}$ \\
\hline Religious Diversity Index & $\begin{array}{r}0.1647 \\
(2.4024)\end{array}$ & $\begin{array}{r}1.6567 \\
(2.1792)\end{array}$ & $\begin{array}{l}-0.6818 \\
(0.5211)\end{array}$ & $\begin{array}{l}-0.5477 \\
(0.4969)\end{array}$ \\
\hline Year FE & Yes & Yes & Yes & Yes \\
\hline Congregation FE & Yes & Yes & Yes & Yes \\
\hline Congregation time trend & Yes & Yes & Yes & Yes \\
\hline$R^{2}$ & 0.9623 & - & 0.9341 & - \\
\hline No. obs. & 1,220 & 1,136 & 1,168 & 1,108 \\
\hline
\end{tabular}

Notes: The dependent variable is log total receipts (measured at congregation level). High (low) segregation sample is the sample for which the values of the segregation index (see Section 6.2) exceed (are smaller than) the median value (45) defined on the basis of all observations. Models (1) and (3) are estimated using fixed effects (FE) "within" estimator. Models (2) and (4) are estimated using fixed effects instrumental variable/two-stage least squares (FE-IV/2SLS) approach, where the instrument for \% White is its decennial lag (first-stage results are substantively similar to those reported in Table 12 and hence not reported). Heteroskedasticity-robust

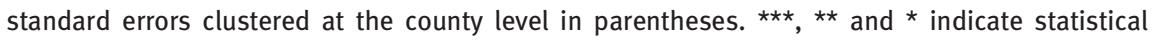
significance at the $1 \%, 5 \%$ and $10 \%$ levels, respectively. ${ }^{+}$indicates statistical significance for one-sided test (for two-sided test, $p$-value equals 0.170 ).

to lead a more racially segregated life, which possibly perpetuates any prejudice against racial and ethnic out-groups.

To explore whether the distinction between urban and rural communities is consequential in our context, we re-estimate our regressions after stratifying the 
sample based on urban versus rural categorization of counties. To sort counties into urban versus rural, we use the urban-rural classification of US counties by the National Center for Health Statistics (NCHS). We rely on NCHS classification from two distinct time periods in order to take into account any changes in the communities' urban versus rural status over the period covered by our data. Specifically, we use the 1990 NCHS classification to designate as urban or rural congregation-year observations from years 1980 and 1990. We use the 2006 NCHS classification to designate as urban or rural congregation-year observations from years 2000 and 2010. Panels B and C of Tables 2 and 13 present the descriptive statistics for the urban and rural sample. On average, religious giving per member is higher for urban congregations. There exists no difference between urban and rural congregations in terms of Sunday school attendance per member. Median income and education are on average higher in urban than in rural areas. The mean percent of whites for our sample is somewhat higher in urban than in rural communities.

Table 6 summarizes the urban versus rural results for the two preferred empirical specifications: fixed effects with the maximum number of congregation-level and county-level controls (as in column (4) of Table 4) and fixed effects IV approach (as in column (5) of Table 4). The results suggest that urban versus rural status of the community indeed matters and, furthermore, that our results on the effect of percent of whites in the full sample (Tables 3 and 4) are driven by urban congregations. The effect of percent of whites on religious giving is statistically significant in the urban sample when using the IV approach (column (2)). The coefficient on the percent of whites in the rural sample is not statistically significant (see columns (3) and (4)). These results, therefore, do not support the hypothesis that racial in-group bias is stronger in

rural communities (e. g.,, because there exists an educational gap between rural and urban communities). Instead, our results are consistent with the alternative hypothesis that, in part by the virtue of their size and independent of the extent of residential racial segregation, urban communities enable the individuals, if they so choose, to lead a more racially segregated life than the relatively smaller rural communities. This, in turn, plausibly perpetuates biases against racial outgroups in urban communities (see, e. g., Pettigrew and Tropp 2006).

\subsection{Alternative Specifications}

We explore the sensitivity of our results to using an alternative outcome variable, log of total receipts per resident member. Table 13 provides the descriptive statistics for (unlogged) total receipts per resident member. In the corresponding 
Table 6: Results, urban versus rural communities.

\begin{tabular}{|c|c|c|c|c|}
\hline \multirow[t]{2}{*}{ Explanatory variables } & \multicolumn{2}{|r|}{ Urban } & \multicolumn{2}{|r|}{ Rural } \\
\hline & (1) $\mathrm{FE}$ & (2) $\mathrm{FE}-\mathrm{IV} / 2 \mathrm{SLS}$ & (3) FE & (4) $\mathrm{FE}-\mathrm{IV} / 2 \mathrm{SLS}$ \\
\hline$\%$ White (in county) & $\begin{array}{r}0.0040 \\
(0.0048)\end{array}$ & $\begin{array}{l}0.0392^{\star \star \star} \\
(0.0144)\end{array}$ & $\begin{array}{r}0.0041 \\
(0.0092)\end{array}$ & $\begin{array}{l}-0.0163 \\
(0.0343)\end{array}$ \\
\hline \multicolumn{5}{|l|}{ Congregation level } \\
\hline Log Resident membership & $\begin{array}{l}0.3287^{\star \star \star} \\
(0.0374)\end{array}$ & $\begin{array}{l}0.2499^{\star * \star} \\
(0.0368)\end{array}$ & $\begin{array}{l}0.3275^{\star \star \star} \\
(0.0269)\end{array}$ & $\begin{array}{l}0.2816^{\star \star \star \star} \\
(0.0330)\end{array}$ \\
\hline Log Sunday school attendance & $\begin{array}{l}0.4914^{\star \star \star} \\
(0.0559)\end{array}$ & $\begin{array}{l}0.5238^{\star * *} \\
(0.0759)\end{array}$ & $\begin{array}{l}0.4540^{\star \star \star \star} \\
(0.0324)\end{array}$ & $\begin{array}{l}0.4975^{\star * \star} \\
(0.0359)\end{array}$ \\
\hline \multicolumn{5}{|l|}{ County level } \\
\hline Median income (in USD 1,000 ) & $\begin{array}{l}-0.0016 \\
(0.0075)\end{array}$ & $\begin{array}{l}-0.0151 \\
(0.0091)\end{array}$ & $\begin{array}{r}0.0012 \\
(0.0060)\end{array}$ & $\begin{array}{r}0.0137 \\
(0.0126)\end{array}$ \\
\hline$\%$ Families in poverty & $\begin{array}{l}-0.0023 \\
(0.0122)\end{array}$ & $\begin{array}{r}0.0104 \\
(0.0205)\end{array}$ & $\begin{array}{r}0.0000 \\
(0.0046)\end{array}$ & $\begin{array}{r}0.0058 \\
(0.0061)\end{array}$ \\
\hline$\%$ College degree & $\begin{array}{r}0.0115 \\
(0.0183)\end{array}$ & $\begin{array}{l}-0.0312 \\
(0.0309)\end{array}$ & $\begin{array}{r}0.0081 \\
(0.0125)\end{array}$ & $\begin{array}{l}-0.0047 \\
(0.0216)\end{array}$ \\
\hline Population density & $\begin{array}{l}-0.0001 \\
(0.0001)\end{array}$ & $\begin{array}{r}0.0002 \\
(0.0002)\end{array}$ & $\begin{array}{r}0.0011 \\
(0.0017)\end{array}$ & $\begin{array}{l}-0.0015 \\
(0.0030)\end{array}$ \\
\hline Religious Diversity Index & $\begin{array}{r}0.5635 \\
(0.5752)\end{array}$ & $\begin{array}{r}0.4795 \\
(0.7250)\end{array}$ & $\begin{array}{l}-0.2166 \\
(0.3576)\end{array}$ & $\begin{array}{l}-0.2374 \\
(0.4073)\end{array}$ \\
\hline Year FE & Yes & Yes & Yes & Yes \\
\hline Congregation FE & Yes & Yes & Yes & Yes \\
\hline Congregation time trend & Yes & Yes & Yes & Yes \\
\hline$R^{2}$ & 0.9279 & - & 0.9270 & - \\
\hline No. obs. & 1,980 & 1,418 & 2,643 & 1,860 \\
\hline
\end{tabular}

Notes: The dependent variable is log total receipts (measured at congregation level). Models (1) and (3) are estimated using fixed effects (FE) "within" estimator. Models (2) and (4) are estimated using fixed effects instrumental variable/two-stage least squares (FE-IV/2SLS) approach, where the instrument for \% White is its decennial lag (first-stage results are substantively similar to those reported in Table 12 and hence not reported). Heteroskedasticity-robust standard errors clustered at the county level in parentheses. ${ }^{\star \star \star}$, ** and * indicate statistical significance at the $1 \%, 5 \%$ and $10 \%$ levels, respectively.

specifications we further separately control for resident membership in order to test for free-riding effects in religious giving, a phenomenon found to be empirically salient in previous research on the topic (see, e. g., Zaleski and Zech 1992, 1996). Table 7 presents the results by sample (full, urban and rural) for fixed effects specification with the maximum number of congregation-level and county-level controls (as featured in column (4) of Table 4) and for the fixed effects IV approach (as featured in column (5) of Table 4). Consistent with the 
Table 7: Robustness checks, alternative outcome variable.

\begin{tabular}{|c|c|c|c|c|c|c|}
\hline \multirow{2}{*}{$\begin{array}{l}\text { Explanatory } \\
\text { variables }\end{array}$} & \multicolumn{2}{|r|}{ Full } & \multicolumn{2}{|r|}{ Urban } & \multicolumn{2}{|r|}{ Rural } \\
\hline & (1) $\mathrm{FE}$ & $\begin{array}{r}\text { (2) FE-IV/ } \\
2 \mathrm{SLS}\end{array}$ & (3) $\mathrm{FE}$ & $\begin{array}{r}\text { (4) } \mathrm{FE}-\mathrm{IV} / \\
2 \mathrm{SLS}\end{array}$ & (5) $\mathrm{FE}$ & $\begin{array}{r}\text { (6) } \mathrm{FE}-\mathrm{IV} / \\
2 \mathrm{SLS}\end{array}$ \\
\hline$\%$ White (in county) & $\begin{array}{l}0.0092^{\star *} \\
(0.0045)\end{array}$ & $\begin{array}{l}0.0249 * * * \\
(0.0092)\end{array}$ & $\begin{array}{r}0.0040 \\
(0.0048)\end{array}$ & $\begin{array}{l}0.0392^{\star \star *} \\
(0.0144)\end{array}$ & $\begin{array}{r}0.0042 \\
(0.0092)\end{array}$ & $\begin{array}{l}-0.0049 \\
(0.0102)\end{array}$ \\
\hline \multicolumn{7}{|l|}{ Congregation level } \\
\hline $\begin{array}{l}\text { Log Resident } \\
\text { membership }\end{array}$ & $\begin{array}{l}-0.6698^{\star \star \star} \\
(0.0220)\end{array}$ & $\begin{array}{l}-0.7103^{\star \star \star} \\
(0.0221)\end{array}$ & $\begin{array}{l}-0.6713^{\star \star \star} \\
(0.0374)\end{array}$ & $\begin{array}{l}-0.7501^{\star \star \star} \\
(0.0368)\end{array}$ & $\begin{array}{l}-0.6725^{\star \star \star} \\
(0.0270)\end{array}$ & $\begin{array}{l}-0.7156^{\star \star \star} \\
(0.0325)\end{array}$ \\
\hline $\begin{array}{l}\text { Log Sunday school } \\
\text { attendance }\end{array}$ & $\begin{array}{l}0.4633^{\star \star *} \\
(0.0299)\end{array}$ & $\begin{array}{l}0.4952^{\star \star \star} \\
(0.0373)\end{array}$ & $\begin{array}{r}0.4914 \\
(0.0559)\end{array}$ & $\begin{array}{l}0.5238^{\star \star \star} \\
(0.0759)\end{array}$ & $\begin{array}{l}0.4540^{\star \star \star} \\
(0.0324)\end{array}$ & $\begin{array}{l}0.4958^{\star \star \star} \\
(0.0364)\end{array}$ \\
\hline \multicolumn{7}{|l|}{ County level } \\
\hline $\begin{array}{l}\text { Median income (in } \\
\text { USD } 1,000 \text { ) }\end{array}$ & $\begin{array}{r}0.0011 \\
(0.0038)\end{array}$ & $\begin{array}{l}-0.0015 \\
(0.0044)\end{array}$ & $\begin{array}{l}-0.0017 \\
(0.0075)\end{array}$ & $\begin{array}{l}-0.0151 \\
(0.0090)\end{array}$ & $\begin{array}{r}0.0012 \\
(0.0060)\end{array}$ & $\begin{array}{r}0.0086 \\
(0.0061)\end{array}$ \\
\hline $\begin{array}{l}\% \text { Families in } \\
\text { poverty }\end{array}$ & $\begin{array}{l}-0.0006 \\
(0.0041)\end{array}$ & $\begin{array}{r}0.0009 \\
(0.0059)\end{array}$ & $\begin{array}{l}-0.0023 \\
(0.0122)\end{array}$ & $\begin{array}{r}0.0104 \\
(0.0205)\end{array}$ & $\begin{array}{r}0.0000 \\
(0.0046)\end{array}$ & $\begin{array}{r}0.0034 \\
(0.0055)\end{array}$ \\
\hline$\%$ College degree & $\begin{array}{r}0.0066 \\
(0.0099)\end{array}$ & $\begin{array}{l}-0.0069 \\
(0.0147)\end{array}$ & $\begin{array}{r}0.0120 \\
(0.0183)\end{array}$ & $\begin{array}{l}-0.0312 \\
(0.0309)\end{array}$ & $\begin{array}{r}0.0081 \\
(0.0125)\end{array}$ & $\begin{array}{r}0.0038 \\
(0.0148)\end{array}$ \\
\hline Population density & $\begin{array}{l}-0.0001 \\
(0.0001)\end{array}$ & $\begin{array}{r}0.0001 \\
(0.0002)\end{array}$ & $\begin{array}{l}-0.0000 \\
(0.0001)\end{array}$ & $\begin{array}{r}0.0002 \\
(0.0002)\end{array}$ & $\begin{array}{r}0.0011 \\
(0.0017)\end{array}$ & $\begin{array}{l}-0.0001 \\
(0.0020)\end{array}$ \\
\hline $\begin{array}{l}\text { Religious Diversity } \\
\text { Index }\end{array}$ & $\begin{array}{l}-0.0549 \\
(0.3164)\end{array}$ & $\begin{array}{r}0.1229 \\
(0.4277)\end{array}$ & $\begin{array}{r}0.5635 \\
(0.5752)\end{array}$ & $\begin{array}{r}0.4795 \\
(0.7250)\end{array}$ & $\begin{array}{l}-0.2166 \\
(0.3576)\end{array}$ & $\begin{array}{l}-0.1629 \\
(0.3715)\end{array}$ \\
\hline Year FE & Yes & Yes & Yes & Yes & Yes & Yes \\
\hline Congregation FE & Yes & Yes & Yes & Yes & Yes & Yes \\
\hline $\begin{array}{l}\text { Congregation time } \\
\text { trend }\end{array}$ & Yes & Yes & Yes & Yes & Yes & Yes \\
\hline$R^{2}$ & 0.8025 & - & 0.7928 & - & 0.8289 & - \\
\hline No. obs. & 4,623 & 3,278 & 1,980 & 1,418 & 2,643 & 1,860 \\
\hline
\end{tabular}

Notes: The dependent variable is log total receipts per resident member (measured at congregation level). Models (1), (3) and (5) are estimated using fixed effects (FE) "within" estimator. Models (2), (4) and (6) are estimated using fixed effects instrumental variable/two-stage least squares (FE-IV/2SLS) approach, where the instrument for \% White is its decennial lag (first-stage results are substantively similar to those reported in Table 12 and hence not reported). Heteroskedasticity-robust standard errors clustered at the county level in parentheses. ${ }^{\star \star *}$, ** and * indicate statistical significance at the $1 \%, 5 \%$ and $10 \%$ levels, respectively.

findings reported in Tables 4 and 6, the effect of percent of whites on religious giving is positive and statistically significant in full and urban samples (columns (1)-(4)), and statistically insignificant in the rural sample (columns (5) and (6)). Consistent with the free-riding hypothesis, the coefficient on logged resident membership is negative and statistically significant across all specifications.

We also test the robustness of our findings to replacing the controls logged resident membership and logged Sunday school attendance with the ratio of 
Table 8: Robustness checks, normalizing Sunday school attendance with resident membership.

\begin{tabular}{|c|c|c|c|c|c|c|}
\hline \multirow[t]{2}{*}{ Explanatory variables } & \multicolumn{2}{|r|}{ Full } & \multicolumn{2}{|r|}{ Urban } & \multicolumn{2}{|r|}{ Rural } \\
\hline & (1) $\mathrm{FE}$ & $\begin{array}{r}\text { (2) } \mathrm{FE}-\mathrm{IV} / \\
2 \mathrm{SLS}\end{array}$ & (3) $\mathrm{FE}$ & $\begin{array}{r}\text { (4) } \mathrm{FE}-\mathrm{IV} / \\
2 \mathrm{SLS}\end{array}$ & (5) $\mathrm{FE}$ & $\begin{array}{r}\text { (6) } \mathrm{FE}-\mathrm{IV} / \\
2 \mathrm{SLS}\end{array}$ \\
\hline$\%$ White (in county) & $\begin{array}{l}0.0221^{\star \star \star *} \\
(0.0067)\end{array}$ & $\begin{array}{l}0.0556^{\star * *} \\
(0.0143)\end{array}$ & $\begin{array}{l}0.0387^{\star * \star} \\
(0.0074)\end{array}$ & $\begin{array}{l}0.0915^{\star \star \star} \\
(0.0145)\end{array}$ & $\begin{array}{r}0.0088 \\
(0.0126)\end{array}$ & $\begin{array}{r}0.0126 \\
(0.0595)\end{array}$ \\
\hline Congregation level & & & & & & \\
\hline $\begin{array}{l}\text { Sunday school } \\
\text { attendance per } \\
\text { resident member }\end{array}$ & $\begin{array}{l}0.0785^{\star} \\
(0.0435)\end{array}$ & $\begin{array}{l}0.1329 * \star \star \\
(0.0486)\end{array}$ & $\begin{array}{r}0.1308 \\
(0.0890)\end{array}$ & $\begin{array}{l}0.2140^{\star \star \star} \\
(0.1216)\end{array}$ & $\begin{array}{r}0.0600 \\
(0.0454)\end{array}$ & $\begin{array}{l}0.1013^{\star \star} \\
(0.0438)\end{array}$ \\
\hline County level & & & & & & \\
\hline $\begin{array}{l}\text { Median income (in } \\
\text { USD 1,000) }\end{array}$ & $\begin{array}{r}0.0085 \\
(0.0055)\end{array}$ & $\begin{array}{l}-0.0004 \\
(0.0059)\end{array}$ & $\begin{array}{r}0.0005 \\
(0.0088)\end{array}$ & $\begin{array}{l}-0.0196^{\star \star} \\
(0.0094)\end{array}$ & $\begin{array}{r}0.0077 \\
(0.0086)\end{array}$ & $\begin{array}{r}0.0068 \\
(0.0214)\end{array}$ \\
\hline$\%$ Families in poverty & $\begin{array}{r}0.0037 \\
(0.0056)\end{array}$ & $\begin{array}{r}0.0051 \\
(0.0070)\end{array}$ & $\begin{array}{r}0.0074 \\
(0.0138)\end{array}$ & $\begin{array}{r}0.0168 \\
(0.0206)\end{array}$ & $\begin{array}{r}0.0041 \\
(0.0069)\end{array}$ & $\begin{array}{r}0.0066 \\
(0.0089)\end{array}$ \\
\hline$\%$ College degree & $\begin{array}{r}0.0089 \\
(0.0135)\end{array}$ & $\begin{array}{l}-0.0125 \\
(0.0205)\end{array}$ & $\begin{array}{r}0.0026 \\
(0.0180)\end{array}$ & $\begin{array}{l}-0.0524 \\
(0.0402)\end{array}$ & $\begin{array}{r}0.0071 \\
(0.0158)\end{array}$ & $\begin{array}{r}0.0075 \\
(0.0328)\end{array}$ \\
\hline Population density & $\begin{array}{r}0.0002 \\
(0.0002)\end{array}$ & $\begin{array}{r}0.0005 \\
(0.0003)\end{array}$ & $\begin{array}{r}0.0002 \\
(0.0001)\end{array}$ & $\begin{array}{l}0.0005^{\star *} \\
(0.0002)\end{array}$ & $\begin{array}{l}0.0054^{\star \star} \\
(0.0026)\end{array}$ & $\begin{array}{r}0.0038 \\
(0.0051)\end{array}$ \\
\hline $\begin{array}{l}\text { Religious Diversity } \\
\text { Index }\end{array}$ & $\begin{array}{l}-0.2452 \\
(0.3804)\end{array}$ & $\begin{array}{r}0.2496 \\
(0.5916)\end{array}$ & $\begin{array}{r}0.1129 \\
(0.5333)\end{array}$ & $\begin{array}{r}0.6701 \\
(0.8163)\end{array}$ & $\begin{array}{l}-0.5192 \\
(0.4026)\end{array}$ & $\begin{array}{l}-0.6601 \\
(0.4877)\end{array}$ \\
\hline Year FE & Yes & Yes & Yes & Yes & Yes & Yes \\
\hline Congregation FE & Yes & Yes & Yes & Yes & Yes & Yes \\
\hline $\begin{array}{l}\text { Congregation time } \\
\text { trend }\end{array}$ & Yes & Yes & Yes & Yes & Yes & Yes \\
\hline$R^{2}$ & 0.8942 & - & 0.8922 & - & 0.8916 & - \\
\hline No. obs. & 4,623 & 3,278 & 1,980 & 1,418 & 2,643 & 1,860 \\
\hline
\end{tabular}

Notes: The dependent variable is log total receipts (measured at congregation level). Models (1), (3) and (5) are estimated using fixed effects (FE) "within" estimator. Models (2), (4) and (6) are estimated using fixed effects instrumental variable/two-stage least squares approach (FE-IV/2SLS), where the instrument for \% White is its decennial lag (first-stage results are substantively similar to those reported in Table 12 and hence not reported). Heteroskedasticity-robust standard errors clustered at the county level in parentheses. ${ }^{* *}$, ** and * indicate statistical significance at the $1 \%, 5 \%$ and $10 \%$ levels, respectively.

Sunday school attendance to resident membership. Table 13 presents the descriptive statistics by sample for this variable. Table 8 presents the results. The effect of percent of whites on religious giving continues to be positive and statistically significant in the full and urban sample (columns (1)-(4)), and statistically insignificant in the rural sample (columns (5) and (6)). The effect of Sunday school attendance per resident member on religious giving is positive and statistically significant across all specifications. 


\subsection{Testing for White Flight}

One might still be concerned that our results are driven by white flight rather than racial group affinity. Given lack of time-varying proxies for the wealth of congregation members, the inclusion of congregation-specific time trends may not control fully satisfactorily for simultaneous changes in the racial composition of the county and white-flight-induced wealth composition of the congregation membership, which in turn affects giving. Moreover, the lagged percent of whites in the county could reflect past occurrences of white flight. If the consequences of historic episodes of white flight persist over time (Hungerman 2008, 388), our IV does not satisfy the exclusion restriction, rendering our IV approach invalid.

If white flight is salient in our data, we should detect a statistically significant positive association between the percent of whites in the county and either the income level of the most affluent county residents or the share of county residents belonging to the highest income bracket. The results in Table 9 suggest that is not the case. The percent of whites in the county in our sample is in fact negatively and statistically insignificantly associated with the share of county residents falling in the highest income bracket (column (1)). Similarly, the coefficient on the percent of whites in the county is statistically insignificant

Table 9: Test of the presence of white flight.

\begin{tabular}{lrrrr}
\hline Explanatory variables & $(1)$ & $(2)$ & (3) & (4) \\
\hline$\%$ White (in county) & -0.0287 & 119.84 & 73.33 & 47.42 \\
& $(0.1266)$ & $(175.77)$ & $(196.37)$ & $(260.39)$ \\
County FE & Yes & Yes & Yes & Yes \\
Year FE & Yes & Yes & Yes & Yes \\
$R^{2}$ & 0.9133 & 0.9702 & 0.9706 & 0.9705 \\
No. obs. & 256 & 256 & 256 & 256 \\
\hline
\end{tabular}

Notes: The estimates are based on a panel of counties of the state under consideration pooled over four decades (1980, 1990, 2000 and 2010). The dependent variable in model (1) is the share of households with income equal to or exceeding USD 75,000 as the largest income bracket that is consistently reported by the U.S. Census for the four decades in question. The dependent variable in models (2), (3) and (4) is, respectively, the estimated level of household income at the 80th, 85th, and 90th percentile. The income percentile levels in each of the four decades were estimated using linear approximation on the basis of the actual distribution of households across the income brackets reported by the U.S. Census. (The alternative estimates based on more complex kernel density estimation are very similar. Details on the method of estimation of household income percentiles are available upon request.) Heteroskedasticityrobust standard errors clustered at the county level in parentheses. ${ }^{* \star}$, ${ }^{\star *}$ and $*$ indicate statistical significance at the $1 \%, 5 \%$ and $10 \%$ levels, respectively. FE, fixed effects. 
(albeit positive) in the regressions where the dependent variable is an estimate of household income at either the 80th, 85th or 90th percentile (columns (2)-(4)). These additional estimates lead us to dismiss with a high level of confidence the concern that our results may be driven by white flight.

\subsection{Racial Group Affinity Motive versus Fortress-Building Motive}

The robust positive association between percent whites in the community and religious giving in our data is fully consistent with the racial group affinity motive. Greater racial diversity in the community (i. e., lower percent of whites), however, may also induce the congregations to increase their spending on congregation club goods as opposed to goods and services that benefit the wider community. Given the mission of the SCC in question, which entails a strong and repeated emphasis on inclusiveness and a commitment to reach out to everyone in the community (see Section 2), we expect the club good aspect of congregations' activity and the associated "fortress-building" motive in religious giving to be at best of minor importance. We also explore this argument empirically.

A test of the fortress-building motive would entail an examination of the relationship between the percent of whites in the community and the composition of expenditures and services provided by the congregation. Specifically, if a decrease in the percent of whites in the county were associated with congregations' increased emphasis on activities that benefit solely or primarily the congregation's members (as opposed to wider community), we could conclude that the fortress-building motive is an important alternative motive driving religious giving. Unfortunately, the lack of data on congregations' spending in our dataset (see Section 4) prevents us from performing such a test. We instead utilize the available data on congregations' missionary activities for year 2010 (the only year for which such information is provided) to examine whether there exists an association between the congregation-level number of missionaries on local missions or, alternatively, the share of all missionaries on local missions, respectively, and the percent of whites in the community. If the fortress-building motive is important, a decrease in the percent of whites in the county should be associated with a congregation's increased orientation toward spending on club goods and given limited resources, hence, a decreased emphasis on local missionary activities which benefit the congregation's wider (and now more diverse) community; that is, we would expect that the number and share of local missionaries are positively associated with the percent of whites in the county. 
Table 10: Test of fortress-building motive.

\begin{tabular}{|c|c|c|c|c|}
\hline \multirow[t]{2}{*}{ Explanatory variables } & \multicolumn{2}{|r|}{ Panel A } & \multicolumn{2}{|r|}{ Panel B } \\
\hline & (1) & (2) & (3) & (4) \\
\hline$\%$ White (in county) & $\begin{array}{l}-0.0058 \\
(0.0043)\end{array}$ & $\begin{array}{l}-0.0027 \\
(0.0063)\end{array}$ & $\begin{array}{l}-0.0009 \\
(0.0012)\end{array}$ & $\begin{array}{l}-0.0001 \\
(0.0023)\end{array}$ \\
\hline Congregation-level controls & No & Yes & No & Yes \\
\hline County-level controls & No & Yes & No & Yes \\
\hline$R^{2}$ & 0.0017 & 0.3203 & 0.0008 & 0.0237 \\
\hline No. obs. & 1,103 & 1,103 & 633 & 633 \\
\hline
\end{tabular}

Notes: Ordinary least square regressions using year 2010 cross section of congregations. The dependent variable in Panel A is logged value of Local Missionaries + 1 (measured at congregation level). The dependent variable in Panel B is Share Local Missionaries (measured at the congregation level). Congregation-level controls are log resident membership, log Sunday school attendance and log total receipts. County-level controls are median income, \% families in poverty, $\%$ college degree, population density and Religious Diversity Index. Heteroskedasticity-robust standard errors clustered at the county level in parentheses. ${ }^{* \star},{ }^{* \star}$ and * indicate statistical significance at the $1 \%, 5 \%$ and $10 \%$ levels, respectively.

The results in Table 10 suggest this is not the case: regardless of whether we utilize a simple bivariate regression or a multiple-regression framework with a full set of county- and congregation-level controls, including the log of total receipts (to take into account that congregations' activities depend on collected charitable donations), the coefficient on percent whites is negative and statistically insignificant. Hence, we do not find evidence consistent with the fortressbuilding motive and club good dimension of congregation activity.

It is also important to emphasize that any presence of the fortress-building motive potentially not uncovered by the above simple test in no way invalidates our results about the importance of the racial group affinity motive. The fortressbuilding and racial group affinity hypotheses entail opposing predictions concerning the direction of the effect of percent of whites on religious giving, with the latter predicting a negative and the former a positive effect. Thus, to the extent that the fortress-building motive provides a partial explanation for religious giving, the robust positive effect of percent whites in the community on religious giving in our data underestimates the true effect due to the racial group affinity motive.

\subsection{Testing for Sample Selection Bias}

Finally, given the unbalanced nature of our panel, a concern might be that our results suffer from selection bias that would arise if congregations are entering 
and exiting the religious market based on their ability to collect religious contributions. To test for the presence of selection bias, we ran the Nijman and Verbeek (1992) test advocated by Wooldridge (2002, 581). We constructed a selection dummy equal to 1 if congregation $k$ is part of the panel in year $t$ and 0 otherwise, included either a ten-year lagged or a ten-year lead value of the selection indicator in our regressions, and conducted a $t$-test of the null hypothesis that the coefficient on the lagged or lead selection indicator, respectively, equals 0 . Under the null hypothesis, selection in the future or past decade should not be significant in the estimated model for time $t$ with logged total receipts as the outcome variable. In none of the preferred specifications (results not reported) was the coefficient on the lagged or lead selection indicator found to be statistically significantly different from 0 . Therefore, our unbalanced panel does not suffer from selection bias.

\section{Conclusion}

Beyond being "a virtue in and of itself” (Andreoni et al. 2011, 2), diversity confers many socioeconomic benefits (see, e. g., Alesina and Ferrara 2005; Page 2007). Recent empirical research, however, has also illuminated a less advantageous side of diverse communities: greater heterogeneity within communities is associated with reduced contributions toward goods and activities that confer public benefits. We contribute to this research by examining whether, and if so to what extent, a quantitatively very important component of total charitable giving in the United States - religious giving - is in part driven by racial group affinity motives; that is, the positive dependence of religious contributions on the share of one's own racial group in the local community.

The panel structure of our novel congregation-level panel dataset allows us to confront the problem presented by unobserved congregation-level heterogeneity to a fuller extent than the existing studies on the sensitivity of religious giving and church charitable activity to local communities' racial composition. Consistent with the racial group affinity theory, our analysis implies that an increase in racial diversity in the community, in particular in urban areas, results in a nontrivial reduction in religious giving. Given the substantial involvement of congregations in the provision of various social services, these findings have implications for private provision of public goods.

Finally, we emphasize that our analysis is purely positive, and not normative, in character. In addition, we focus on congregations of a single religious denomination in one US state. While this approach offers clear benefits in terms of our ability to empirically assess the presence of the racial group affinity 
motive, further research should seek to test the racial group affinity hypothesis in a broader context.

Acknowledgments: We are grateful to the representative of the denomination which is the subject of our analysis, for giving us permission to use the data and for assisting us in the process of dataset assembly, as well as to Sam Allen, Atin Basu, Jon Eastwood, Sara Helms, Bryan McCannon, Paul Pecorino, Katie Shester, Jeff Smith, Mark Wilson, participants at the annual meeting of the Southern Economic Association, two anonymous reviewers and the editor Hendrik Juerges for helpful comments and suggestions.

\section{Appendix}

Table 11: Summary statistics by year, main variables.

\begin{tabular}{|c|c|c|c|c|c|}
\hline Variable name & No. obs. & Mean & Std. dev. & Min. & Max. \\
\hline \multicolumn{6}{|l|}{ Year 1980} \\
\hline \multicolumn{6}{|l|}{ Congregation level } \\
\hline Total receipts (in USD) & 1,132 & $91,042.6$ & $178,142.9$ & 1228.0 & $1,935,710.0$ \\
\hline Resident membership & 1,132 & 299.5 & 376.4 & 11 & 3,958 \\
\hline Sunday school attendance & 1,132 & 106.4 & 161.1 & 6 & 1,873 \\
\hline \multicolumn{6}{|l|}{ County level } \\
\hline$\%$ White & 61 & 70.3 & 13.2 & 37.9 & 95.7 \\
\hline Median income (in USD) & 61 & $13,801.2$ & $3,690.9$ & $7,780.0$ & $21,063.0$ \\
\hline$\%$ Families in poverty & 61 & 18.1 & 6.5 & 7.4 & 34.2 \\
\hline$\%$ College degree & 61 & 5.4 & 1.6 & 2.7 & 9.3 \\
\hline Population density & 61 & 110.6 & 217.8 & 5.2 & $1,486.1$ \\
\hline Religious Diversity Index & 61 & 0.248 & 0.113 & 0.088 & 0.662 \\
\hline \multicolumn{6}{|l|}{ Year 1990} \\
\hline \multicolumn{6}{|l|}{ Congregation level } \\
\hline Total receipts (in USD) & 1,230 & $139,623.2$ & $286,737.5$ & 926.0 & $3,725,936.0$ \\
\hline Resident membership & 1,230 & 297.7 & 410.0 & 10 & 4,565 \\
\hline Sunday school attendance & 1,230 & 111.8 & 189.8 & 6 & 2,262 \\
\hline \multicolumn{6}{|l|}{ County level } \\
\hline$\%$ White & 58 & 68.6 & 13.2 & 34.6 & 94.0 \\
\hline Median income (in USD) & 58 & $19,554.0$ & $4,674.0$ & $9,791.0$ & $31,777.0$ \\
\hline$\%$ Families in poverty & 58 & 22.6 & 7.3 & 11.2 & 51.2 \\
\hline$\%$ College degree & 58 & 10.0 & 2.7 & 6.6 & 18.2 \\
\hline Population density & 58 & 112.5 & 225.3 & 7.1 & $1,465.5$ \\
\hline Religious Diversity Index & 58 & 0.259 & 0.103 & 0.084 & 0.543 \\
\hline
\end{tabular}


Table 11: (continued)

\begin{tabular}{|c|c|c|c|c|c|}
\hline Variable name & No. obs. & Mean & Std. dev. & Min. & Max. \\
\hline \multicolumn{6}{|l|}{ Year 2000} \\
\hline \multicolumn{6}{|l|}{ Congregation level } \\
\hline Total receipts (in USD) & 1,158 & $244,901.4$ & $683,867.4$ & 75.0 & $14,308,447.0$ \\
\hline Resident membership & 1,158 & 310.9 & 456.9 & 8 & 5,569 \\
\hline Sunday school attendance & 1,158 & 116.8 & 237.5 & 6 & 3,015 \\
\hline \multicolumn{6}{|l|}{ County level } \\
\hline$\%$ White & 57 & 65.5 & 13.8 & 31.6 & 94.3 \\
\hline Median income (in USD) & 57 & $29,332.0$ & $6,003.3$ & $19,799.0$ & $45,139.0$ \\
\hline$\%$ Families in poverty & 57 & 18.4 & 5.3 & 9.1 & 32.9 \\
\hline$\%$ College degree & 57 & 12.3 & 2.3 & 8.4 & 18.2 \\
\hline Population density & 57 & 112.3 & 233.4 & 7.6 & $2,488.9$ \\
\hline Religious Diversity Index & 57 & 0.263 & 0.107 & 0.095 & 0.516 \\
\hline \multicolumn{6}{|l|}{ Year 2010} \\
\hline \multicolumn{6}{|l|}{ Congregation level } \\
\hline Total receipts (in USD) & 1,103 & $318,997.7$ & $791,658.3$ & 434.0 & $10,706,728.0$ \\
\hline Resident membership & 1,103 & 293.1 & 501.0 & 7 & 5,083 \\
\hline Sunday school attendance & 1,103 & 105.8 & 232.8 & 6 & 3,156 \\
\hline \multicolumn{6}{|l|}{ County level } \\
\hline$\%$ White & 53 & 63.6 & 13.5 & 28.1 & 91.9 \\
\hline Median income (in USD) & 53 & $37,282.6$ & $8,050.7$ & $21,994.0$ & $60,874.0$ \\
\hline$\%$ Families in poverty & 53 & 17.3 & 6.5 & 7.2 & 44.5 \\
\hline$\%$ College degree & 53 & 14.1 & 2.3 & 10.9 & 20.2 \\
\hline Population density & 53 & 120.3 & 243.2 & 8.7 & $3,087.0$ \\
\hline Religious Diversity Index & 53 & 0.159 & 0.086 & 0.034 & 0.389 \\
\hline
\end{tabular}

Notes: The table reports summary statistics for the samples used to generate the results in Tables 3 and 4.

Table 12: First-stage results for fixed effects instrumental variable/two-stage least squares results reported in Tables 3 and 4.

\begin{tabular}{lcc}
\hline Explanatory variable & Table 3, Column (5) & Table 4, Column (5) \\
\hline Ten-year lag of \% White (in county) & $0.6842^{\star \star \star}$ & $0.6817^{\star \star \star}$ \\
& $(0.1306)$ & $(0.1008)$ \\
Congregation level & & \\
Log Resident membership & 0.0175 & -0.0236 \\
& $(0.0924)$ & $(0.1025)$ \\
Log Sunday school attendance & & 0.1029 \\
& & $(0.0887)$
\end{tabular}


Table 12: (continued)

\begin{tabular}{lcc}
\hline Explanatory variable & Table 3, Column (5) & Table 4, Column (5) \\
\hline County level & & \\
Median income (in USD 1,000) & -0.0033 & 0.0482 \\
& $(0.0738)$ & $(0.0790)$ \\
\% Families in poverty & & -0.0171 \\
& & $(0.0840)$ \\
\% College degree & & 0.0500 \\
& & $(0.1610)$ \\
Population density & & $-0.0157^{\star \star \star}$ \\
& & $(0.0038)$ \\
Religious Diversity Index & Yes & $(6.0851)$ \\
& Yes & Yes \\
Year FE & Yes & Yes \\
Congregation FE & 27.5 & Yes \\
Congregation time trend & 3,278 & 45.7 \\
F-stat. excluded instruments & & 3,278 \\
No. obs. & & \\
\hline
\end{tabular}

Notes: The dependent variable is \% White (measured at county level). Heteroskedasticity-robust standard errors clustered at the county level in parentheses. ${ }^{\star \star}$, ** and * indicate statistical significance at the $1 \%, 5 \%$ and $10 \%$ levels, respectively.

Table 13: Summary statistics, additional congregation-level variables.

\begin{tabular}{lrrrrr}
\hline Variable name & No. obs. & Mean & Std. dev. & Min. & Max. \\
\hline Panel A: Full sample & & & & & \\
Total receipts per resident member (in USD) & 4,623 & 565.0 & 623.9 & 0.3 & $24,749.2$ \\
Sunday school attendance per resident member & 4,623 & 0.35 & 0.20 & 0.03 & 5.56 \\
Local missionaries & 1,103 & 26.8 & 175.0 & 0 & 3,913 \\
Share local missionaries & 633 & 0.47 & 0.37 & 0 & 1 \\
Panel B: Urban sample & & & & & \\
Total receipts per resident member (in USD) & 1,980 & 642.2 & 604.6 & 0.3 & $8,423.1$ \\
Sunday school attendance per resident member & 1,980 & 0.35 & 0.18 & 0.03 & 2.93 \\
Panel C: Rural sample & & & & & \\
Total receipts per resident member (in USD) & 2,643 & 507.2 & 631.9 & 11.2 & $24,749.2$ \\
Sunday school attendance per resident member & 2,643 & 0.35 & 0.21 & 0.03 & 5.56 \\
\hline
\end{tabular}

Notes: The table reports summary statistics for samples used to generate the results presented in Tables 7, 8 and 10 . 


\section{References}

Ahmed, A. M. 2007. "Group Identity, Social Distance and Intergroup Bias." Journal of Economic Psychology 28 (3):324-37.

Alesina, A., and E. La Ferrara. 2000. "Participation in Heterogeneous Communities." Quarterly Journal of Economics 115 (3):847-904.

Alesina, A., and E. La Ferrara. 2002. "Who Trusts Others?" Journal of Public Economics 85:207-34.

Alesina, A., and E. La Ferrara. 2005. "Ethnic Diversity and Economic Performance." Journal of Economic Literature 43 (3):762-800.

Alesina, A., R. Baqir, and W. Easterly. 1999. "Public Goods and Ethnic Divisions." Quarterly Journal of Economics 114 (4):1243-84.

Alesina, A., R. Baqir, and W. Easterly. 2000. "Redistributive Public Employment.” Journal of Urban Economics 48 (2):219-41.

Alesina, A., E. Glaeser, and B. Sacerdote. 2001. “Why Doesn't the United States Have a European-Style Welfare State?" Brookings Papers on Economic Activity 2:187-254.

Alesina, A., A. Devleeschauwer, W. Easterly, S. Kurlat, and R. Wacziarg. 2003. "Fractionalization." Journal of Economic Growth 8:155-94.

Andreoni, J., A. Payne, J. D. Smith, and D. Karp. 2011. "Diversity and Donations: The Effect of Religious and Ethnic Diversity on Charitable Giving.” NBER Working Paper No. 17618.

Andreoni, J. 1989. "Giving with Impure Altruism: Applications to Charity and Ricardian Equivalence." Journal of Political Economy 97 (6):1447-58.

Andreoni, J. 1990. "Impure Altruism and Donations to Public Goods: A Theory of Warm-Glow Giving.” Economic Journal 100 (401):464-77.

Andreoni, J. 2006. "Philanthrophy." In Handbook of Giving, Reciprocity and Altruism, edited by S.-C. Kolm, and J. M. Ythier, 1201-69. Amsterdam: North Holland.

Andreoni, J. 2008. "Charitable Giving." In The New Palgrave Dictionary of Economics, 2nd Edition, the New Palgrave Dictionary of Economics Online, edited by S. N. Durlauf, and L. E. Blume. Palgrave Macmillan, doi:10.1057/9780230226203.0221.

Argyle, M., and B. Beit-Hallahmi. 1975. The Social Psychology of Religion. London, UK: Routledge and Kegan Paul.

Ben-Ner, A., B. P. McCall, M. Stephane, and H. Wang. 2009. "Identity and In-Group/Out-Group Differentiation in Work and Giving Behaviors: Experimental Evidence." Journal of Economic Behavior and Organization 72 (1):153-70.

Brewer, M. B. 1979. "In-Group Bias in the Minimal Intergroup Situation: A Cognitive-Motivational Analysis." Psychological Bulletin 86 (2):307-24.

Brown, R. 2000. "Social Identity Theory: Past Achievements, Current Problems and Future Challenges." European Journal of Social Psychology 30 (6):745-78.

Chakravarty, S., and M. A. Fonseca. 2014. "The Effect of Social Fragmentation on Public Good Provision: An Experimental Study.” Journal of Behavioral and Experimental Economics 53:1-9.

Coate, D., and J. Vanderhoff. 2009. "The Effects of County Population Diversity on Contributions, Membership, and Adherents in the Presbyterian Religion and on Adherence in Mainline Protestant Religions." Rutgers University Newark Working Paper No. 2009-003.

Cutler, D. M., E. L. Glaeser, and J. L. Vigdor. 1999. "The Rise and Decline of the American Ghetto." Journal of Political Economy 107 (3):455-506.

Cutler, D. M., D. W. Elmendorf, and R. J. Zeckhauser. 1993. "Demographic Characteristics and the Public Bundle." Public Finance 48:178-98. 
Dahlberg, M., K. Edmark, and H. Lundqvist. 2012. "Ethnic Diversity and Preferences for Redistribution." Journal of Political Economy 120 (1):41-76.

Easterly, W., J. Ritzen, and M. Woolcock. 2006. "Social Cohesion, Institutions and Growth." Economics and Politics 18 (2):103-20.

Eger, M. A. 2010. "Even in Sweden: The Effect of Immigration on Support for Welfare Spending." European Sociological Review 26 (2):203-17.

Festinger, L. 1954. “A Theory of Social Comparison Processes." Human Relations 7:117-40.

Finke, R., and R. Stark. 1988. "Religious Economies and Sacred Canopies: Religious Mobilization in American Cities, 1906." American Sociological Review 53:41-9.

Gächter, S., and B. Herrmann. 2011. "The Limits of Self-Governance When Cooperators Get Punished: Experimental Evidence From Urban and Rural Russia." European Economic Review 55 (2):193-210.

Gerdes, C. 2011. "The Impact of Immigration on the Size of Government: Empirical Evidence From Danish Municipalities.” Scandinavian Journal of Economics 113 (1):74-92.

Goldin, C., and L. F. Katz. 1999. "Human Capital and Social Capital: The Rise of Secondary Schooling in America, 1910 to 1940." Journal of Interdisciplinary History 29 (4):683-723.

Gruber, J. H. 2005. "Religious Market Structure, Religious Participation, and Outcomes: Is Religion Good for You?” The B.E. Journal of Economic Analysis and Policy 5 (1), article 5.

Güth, W., M. Ploner, and T. Regner. 2009. “Determinants of In-Group Bias: Is Group Affiliation Mediated by Guilt-Aversion?” Journal of Economic Psychology 30 (5):814-27.

Hopkins, D. J. 2011. “The Limited Local Impacts of Ethnic and Racial Diversity." American Politics Research 39 (2):344-79.

Hungerman, D. M. 2008. "Race and Charitable Church Activity." Economic Inquiry 46 (3):380-400.

lannaccone, L. R. 1998. "Introduction to the Economics of Religion." Journal of Economic Literature 36:1465-96.

Lopez de Silanes, F., R. La Porta, A. Shleifer, and R. Vishny. 1999. "The Quality of Government.” Journal of Law, Economics, and Organization 15:222-79.

Lincoln, R., C. A. Morrissey, and P. Mundey. 2008. "Religious Giving: A Literature Review." Unpublished manuscript.

Lipford, J. W. 1995. "Group Size and the Free-Rider Hypothesis: An Examination of New Evidence from Churches." Public Choice 83 (3-4):291-303.

Luttmer, E. F. P. 2001. "Group Loyalty and the Taste for Redistribution." Journal of Political Economy 109 (3):500-28.

Marsden, P. V. 1987. “Core Discussion Networks of Americans.” American Sociological Review 52 (1):122-31.

Mullen, B., R. Brown, and C. Smith. 1992. "Ingroup Bias as a Function of Salience, Relevance, and Status: An Integration.” European Journal of Social Psychology 22 (2):103-22.

Miguel, E., and M. K. Gugerty. 2005. "Ethnic Diversity, Social Sanctions, and Public Goods in Kenya." Journal of Public Economics 89 (11-12):2325-68.

Nijman, T., and M. Verbeek. 1992. "Nonresponse in Panel Data: The Impact on Estimates of a Life Cycle Consumption Function." Journal of Applied Econometrics 7:243-57.

Ockenfels, A., and P. Werner. 2014. "Beliefs and Ingroup Favoritism." Journal of Economic Behavior and Organization 108:453-63.

Okten, C., and U. O. Osili. 2004. "Contributions in Heterogeneous Communities: Evidence from Indonesia." Journal of Population Economics 17 (4):603-26.

Page, S. E. 2007. The Difference: How the Power of Diversity Creates Better Groups, Firms, Schools, and Societies. Princeton, NJ: Princeton University Press. 
Pan, X., and D. Houser. 2011. "Mating Strategies and Gender Differences in Pro-sociality: Theory and Evidence." CESifo Economic Studies 57 (4):653-82.

Pettigrew, T. F., and L. R. Tropp. 2006. "A Meta-Analytic Test of Intergroup Contact Theory." Journal of Personality and Social Psychology 90 (5):751-83.

Poterba, J. M. 1997. "Demographic Structure and the Political Economy of Public Education." Journal of Public Policy Analysis and Management 16 (1):48-66.

Ribar, D. C., and M. O. Wilhelm. 2002. "Altruistic and Joy-of-Giving Motivations in Charitable Behavior.” Journal of Political Economy 110 (2):425-57.

Ruffle, B. J., and R. Sosis. 2006. "Cooperation and the In-Group-Out-Group Bias: A Field Test on Israeli Kibbutz Members and City Residents." Journal of Economic Behavior and Organization 60 (2):147-63.

Schervish, P. G., M. A. O'Herlihy, and J. J. Havens. 2006. "Charitable Giving: How Much, by Whom, to What, and How?" In The Nonprofit Sector: A Research Handbook, 2nd edn, edited by W. W. Powell, and R. Steinberg, 542-67. New Haven, CT: Yale University Press.

Senik, C., H. Stichnoth, and K. Van Der Straeten. 2009. "Immigration and Natives' Attitudes towards the Welfare State: Evidence from the European Social Survey." Social Indicators Research 91:345-70.

Solomon, L. D. 2003. In God We Trust? Faith-Based Organizations and the Quest to Solve America's Social Ills. Idaho Falls, ID: Lexington Books.

Staiger, D., and J. H. Stock. 1997. "Instrumental Variables Regression with Weak Instruments." Econometrica 65 (3):557-86.

Stichnoth, H. 2013. "Ethnic Diversity, Public Spending, and Individual Support for the Welfare State: A Review of the Empirical Literature." Journal of Economic Surveys 27 (2):364-89.

Stock, J. H., and M. Yogo. 2005. "Testing for Weak Instruments in Linear IV Regression." In Identification and Inference for Econometric Models: Essays in Honor of Thomas Rothenberg, edited by D. W. K. Andrews, and J. H. Stock, 80-108. London and New York: Cambridge University Press.

Tajfel, H. 1970. “Experiments in Intergroup Discrimination.” Scientific American 223:79-97.

Tajfel, H., M. Billig, R. P. Bundy, and C. Flament. 1971. "Social Categorization and Intergroup Behaviour.” European Journal of Social Psychology 1 (2):149-78.

Vanderhoff, J. 2012. “Economic Diversity, Racial Diversity and Religious Contributions." Rutgers University Newark Working Paper No. 2012-001.

Vigdor, J. L. 2002. “Interpreting Ethnic Fragmentation Effects.” Economics Letters 75:271-6.

Vigdor, J. L. 2004. "Community Composition and Collective Action: Analyzing Initial Mail Response to the 2000 Census." Review of Economics and Statistics 86 (1):303-12.

Wooldridge, J. M. 2002. Econometric Analysis of Cross Section and Panel Data. Cambridge, MA: MIT Press.

Yörük, B. K. 2013. "The Impact of Charitable Subsidies on Religious Giving and Attendance: Evidence from Panel Data." Review of Economics and Statistics 95:1708-21.

Zaleski, P. A., and C. E. Zech. 1992. "Determinants of Contributions to Religious Organizations: Free Riding and Other Factors." American Journal of Economics and Sociology 51 (4):459-72.

Zaleski, P. A., and C. E. Zech. 1995. "The Effect of Religious Market Competition on Church Giving." Review of Social Economy 53 (3):350-67.

Zaleski, P. A., and C. E. Zech. 1996. "Group Size and the Free-Rider Hypothesis: A Re-examination of Old Evidence from Churches: A Comment." Public Choice 88 (3/4):407-11. 